\title{
The anti-oestrogen ICI 182,780, but not tamoxifen, inhibits the growth of MCF-7 breast cancer cells refractory to long-term oestrogen deprivation through down-regulation of oestrogen receptor and IGF signalling
}

\author{
L-A Martin*, S Pancholi*, C M W Chan, I Farmer, C Kimberley, M Dowsett \\ and $S R D$ Johnston ${ }^{1}$
}

Academic Department of Biochemistry, Institute of Cancer Research and ${ }^{1}$ Department of Medicine, Royal Marsden Hospital and Institute of Cancer Research, Fulham Road, London SW3 6JJ, UK

(Requests for offprints should be addressed to L-A Martin; Email: lesley-ann.martin@icr.ac.uk)

*(These authors contributed equally to this work)

\begin{abstract}
Long-term culture of MCF-7 wild-type (wt) cells in steroid-depleted medium (LTED) results in hypersensitivity to oestradiol (E2) coinciding with elevated levels of ER $\alpha$ and enhanced growth factor signalling. In this study, we aimed to compare the effects of the pure anti-oestrogen ICI 182,780 (ICl) with the competitive anti-oestrogen tamoxifen (TAM) on oestrogen and IGF signalling in these cells. Wt MCF-7 and LTED cells were treated with a log 7 concentration range of E2, TAM or ICl. Effects on cell growth, ER $\alpha$ transactivation, expression of ER $\alpha$, ER $\beta$ and components of the IGF pathway were measured with and without insulin. In the presence of insulin, growth of LTED cells was refractory to TAM but inhibited by $I C I$ and E2. In the absence of insulin, LTED cells showed persistent hypersensitivity to $\mathrm{E} 2$, and remained inhibited by $\mathrm{ICl}$ but were largely unaffected by TAM. ICI but not TAM inhibited ER-mediated gene transcription and treatment with ICI resulted in a dose-dependent reduction in ER $\alpha$ levels whilst having no effect on ER $\beta$ expression. IGF-I receptor and insulin receptor substrate 2 levels were increased in LTED versus the Wt MCF-7 cells, and $\mathrm{ICI}$ but not TAM reduced their expression in a dose-dependent fashion. Thus IGF signalling as well as $E R \alpha$ expression and function are enhanced during LTED. While the resultant cells are resistant to TAM, ICl down-regulates $\mathrm{ER} \alpha$, reducing IGF signalling and cell growth. These results support the use of $\mathrm{ICl}$ in women with ER-positive breast cancer who have relapsed on an aromatase inhibitor.
\end{abstract}

Endocrine-Related Cancer (2005) 12 1017-1036

\section{Introduction}

Most patients with oestrogen receptor (ER)-positive advanced breast cancer who have relapsed on tamoxifen (TAM) are prescribed aromatase inhibitors. Unlike TAM, which competes with oestrogen for the ER, aromatase inhibitors block the conversion of androgens to oestrogens removing the proliferative stimuli of the tumour (Buzdar et al. 1998, Dombernowsky et al. 1998). Randomised trials in postmenopausal women with breast cancer have shown that oestrogen deprivation with aromatase inhibitors is superior to TAM as first-line therapy in metastatic disease (Nabholtz et al. 2000, Mouridsen et al. 2001). In the adjuvant setting, preliminary data in ER-positive postmenopausal primary breast cancer 
have shown improved disease-free survival for the aromatase inhibitor anastrozole in comparison with TAM (ATAC Trialists' Group 2002). As a consequence, it is likely that an increasing number of ER-positive postmenopausal women may be treated by oestrogen deprivation as their initial endocrine therapy of choice (Buzdar \& Howell 2001). Despite these advances the majority of women treated with aromatase inhibitors will eventually relapse (for review see Johnston \& Dowsett 2003). As a consequence, understanding the mechanisms involved in resistance to oestrogen deprivation is of major clinical relevance for optimal treatment of breast cancer patients and the development of new therapeutic regimes.

Currently emerging data suggest that endocrine sensitivity may not only be maintained but enhanced when cells become refractory to long-term oestrogen deprivation (LTED). We and others have shown that hormone-sensitive MCF-7 breast cancer cells treated by LTED eventually adapt to residual oestradiol (E2) within their maintenance medium, becoming hypersensitive and maximally growth stimulated at doses as low as ${ }^{-13} \mathrm{M}$ versus $10^{-9} \mathrm{M}$ for parental cells (Masamura et al. 1995, Santen et al. 2001, Chan et al. 2002, Martin et al. 2003). Thus, in the clinical setting, tumour cells may become growth stimulated by the low E2 levels induced by LTED, which would imply that a functional ER signalling pathway remains in these cells. Jeng et al. (1998) previously demonstrated that ER expression and function was up-regulated in MCF-7 LTED cells, although not all oestrogen-responsive genes were activated.

More recent data suggest that an adaptive and complex 'cross-talk' network develops between various growth factor receptor pathways and ER signalling to account for refractory growth (Nicholson et al. 1999, Martin et al. 2003). Cells may utilise these alternative pathways to escape from the constraints of initial oestrogen deprivation therapy, with either the MAP kinase (p42/p44 MAPK) pathway (Coutts \& Murphy 1998, Shim et al. 2000, Martin et al. 2003) or the insulin-like growth factor (IGF) pathway (Stephen et al. 2001) being used to activate ER signalling. We have previously shown that ERBB2 activation of p42/p44 MAPK results in enhanced transcriptional activity of ER in LTED cells (Martin et al. 2003). Evidence for the role of such cross-talk in causing enhanced cell growth and ER signalling was demonstrated by the ability of both an epidermal growth factor receptor (EGFR) tyrosine kinase inhibitor (ZD1839) and a MEK inhibitor (U0126) to inhibit cell proliferation and oestrogen-regulated gene transcription in LTED cells. Further analysis showed that ablation of MAPK reduced the sensitivity of these cells to added E2 but had no effect on phosphorylation of the ER, suggesting that these cells remained ligand dependent (Martin et al. 2003).

An important but unanswered question remains, namely that if ER is expressed and hypersensitive in LTED cells, would an anti-oestrogen still be effective in this setting? It is unclear whether such cells would be cross-resistant with TAM, possibly perceiving TAM as an agonist which might stimulate rather than inhibit growth. It is known that, in general, ER requires a ligand (E2 or TAM) to allow receptor dimerisation and interaction with DNA and, given the enhanced sensitivity of LTED cells to E2, concern might exist about the effect of TAM in this scenario, particularly in view of the fact that ERBB2 may also be upregulated (Martin et al. 2003). ICI 182,780 (ICI) is a steroidal pure anti-oestrogen devoid of agonist activity (Wakeling \& Bowler 1992). In vitro, ICI's binding affinity for the ER is approximately 100 -fold greater than TAM, and in ER-positive MCF-7 breast cancer cells, ICI unlike TAM is a pure antagonist of oestrogen-regulated gene expression (Rajah et al. 1996). ER expression is suppressed and downregulated by ICI, without any concomitant rise in EGFR or transforming growth factor- $\alpha$ (TGF- $\alpha$ ) expression (McClelland et al. 1996).

Other important anti-proliferative effects of ICI include suppression of IGF receptor (IGF-IR) signalling, and previous reports have suggested that ICI, either directly or indirectly, may modulate expression of IGF-IR, IGF-binding proteins (IGFBPs) or the IGF-IR substrate insulin receptor substrate (IRS)-1 (Stewart et al. 1990a, Huynh et al. 1996a,b, Lee et al. 1999, Salerno et al. 1999, Molloy et al. 2000, Chan et al. 2001).

The main aim of this study was to determine the responsiveness of both wild-type (wt) and LTED MCF-7 breast cancer cells to two different antioestrogens, TAM and ICI. In particular, we wished to compare the effect of increasing doses of E2, TAM and ICI on the inhibition of cell growth in both the presence and the absence of exogenous insulin. We investigated the effects of both anti-oestrogens on ER expression (ER $\alpha$ and ER $\beta$ ), and measured changes in ER function in response to TAM and ICI using transient transfection with an oestrogen response-element (ERE) reporter gene. Finally, we examined the changes in IGF signalling in LTED compared with Wt MCF-7 cells, and the effects of TAM and ICI on components of the IGF signalling pathway. 


\section{Materials and Methods}

\section{Materials}

ER $\alpha-6$ F11 antibody was obtained from Novocastra (Newcastle, Tyne and Wear, UK). The ER $\beta$, IRS-1 and IRS-2 antibodies were obtained from Upstate Biotechnology (Dundee, UK). The IGF-IR antibody was purchased from Autogene Bioclear and horseradish peroxidase-conjugated secondary antibody (Amersham Pharmacia Biotech, Amersham, Bucks, UK). 17ß-oestradiol (E2) and TAM were obtained from Sigma (Poole, Dorset, UK). Dr A Wakeling (AstraZeneca Pharmaceuticals, Alderley Edge, Cheshire, UK), kindly provided ICI 182,780. All chemicals, unless otherwise stated, were molecular grade and purchased from Sigma. All tissue culture grade plastics were purchased from Nunc (VWR, Poole, UK).

\section{Tissue culture}

Wt MCF-7 human breast cancer cells were maintained in phenol red-free RPMI 1640 supplemented with $10 \%$ foetal bovine serum (FBS), $10 \mu \mathrm{g} / \mathrm{ml}$ insulin, $2 \mathrm{mM}$ glutamine, 100 units penicillin-streptomycin and $10^{-9} \mathrm{M}$ E2. LTED MCF-7 cells were maintained in medium depleted of steroids and referred to as DCC medium. This was comprised of RPMI 1640 medium containing $2 \mathrm{mM}$ glutamine, 100 units penicillinstreptomycin, $10 \mu \mathrm{g} / \mathrm{ml}$ insulin, $10 \%$ (v/v) dextran charcoal stripped (DCC) FBS. DCC FBS was prepared as previously described (Darbre et al. 1983). The level of E2 after charcoal stripping was quantified by radioimmunoassay (Dowsett et al. 1987) and was routinely less than $4 \mathrm{pmol} / 1\left(4 \times 10^{-12} \mathrm{M}\right)$ which, when added to RPMI 1640 , equated to less than $4 \times 10^{-13} \mathrm{M}$ E2 in the final DCC medium. Cells were passaged weekly and medium was replenished every 2-3 days.

\section{Cell growth assays}

Wt MCF-7 cells were depleted of steroids for 3 days and then seeded into 12-well plates at a density of approximately $1 \times 10^{4}$ cells per well in DCC medium. LTED cells were treated similarly. The cells were left for a further 2 days to acclimatise. Cell monolayers were subsequently treated with E2, TAM or ICI for 6 days with daily changes. The cell number was determined using a Z1 Coulter Counter (Beckman Coulter, High Wycombe, Bucks, UK). In studies determining the effect of insulin on cell growth, both wt and LTED cells were cultured in DCC medium minus insulin for 3 days prior to seeding on 12-well plates. The cells were allowed to acclimatise in DCC medium minus insulin for a further 2 days prior to stimulation with increasing doses of E2, TAM, ICI, vehicle $(0.1 \%(\mathrm{v} / \mathrm{v})$ ethanol) or combinations of the drugs plus or minus $10 \mu \mathrm{g} / \mathrm{ml}$ insulin.

\section{Apoptosis assay}

Apoptosis was measured using the Cell Death Detection ELISA ${ }^{\text {PLUS }}$ (Roche) according to the manufacturer's instructions. In essence, Wt MCF-7 cells (depleted of steroids for 3 days) and LTED cells were seeded into six-well plates at a density of $2 \times 10^{5}$ cells per well in DCC medium. After $48 \mathrm{~h}$, cells were transferred to serum-free medium for $24 \mathrm{~h}$ then treated for $72 \mathrm{~h}$ with DCC medium containing $10 \mu \mathrm{g} / \mathrm{ml}$ insulin plus or minus E2 $\left(10^{-10} \mathrm{M}\right)$.

\section{Real-time quantitative RT-PCR}

Gene expression was assessed using a TaqMan ABI 7900HT (Applied Biosystems, Warrington, Cheshire, UK). mRNA from treated LTED and Wt MCF-7 cells was extracted using RNeasy (Qiagen, UK). The sequences of the primer/probe sets were as follows: ER $\alpha$ : forward (F), 5'-TTCTTCAAGAGAAGTATTCAAGGACATAAC-3', reverse (R), 5'-TCGTATCCCACCTTTCATCATTC- $3^{\prime}$, Probe (P), 5'FAMCCAGCCACCAACCAGTGCACCAT-TAMRA-p-3'; progesterone receptor (PR): F, 5'-ACCTGAGGCCGGATTCAGAA-3', R, 5'-CCACAGGTAAGGACACCATAATGAC-3', P, 5'FAM-CCAGAGCCCACAATACAGCTTCGAGTCATT-TAMRA-p-3'; pS2, F, 5'-GCCCAGACAGAGACGTGTACAG-3', R, 5'GTCGAAACAGCAGCCCTTATTT-3', P, 5'FAMCCCCCGTGAAAGACAGAATTGTGGTTT-TAMRp-3'; c-myc, F, 5'-GCTGCTTAGACGCTGGATTTTT$3^{\prime}$, R, 5'-TTCCTGTTGGTGAAGCTAACGTT-3', P, 5'FAM-TAGTGGAAAACCAGCAGCCTCCCGCGACGA-TAMR-p-3'; cathepsin D, 5'-ACATCGCTTGCTGGATCCA-3', R, 5'-GCTGCCCGAGCCATAGTG-3', P, 5'-FAM-ACAAGTACAACAGCGACAAGTCCAGCACCTA-TAMR-p-3'. Glyceraldehyde-3-phosphate dehydrogenase (GAPDH; Applied Biosystems) was used as a housekeeping gene to normalise the data. Analysis was performed in standard 96-well plates. Reactions were carried out in triplicate using $50 \mathrm{ng}$ mRNA. The relative quantity was determined according to the manufacturer's instructions (Applied Biosystems). In essence, the difference in cycle threshold $(\Delta \mathrm{ct})$ was determined by normalising against GAPDH. $\Delta \Delta \mathrm{ct}$ was then established by normalising against the corrected DCC control. 


\section{Transcriptional assay}

LTED and Wt MCF-7 cells (previously stripped of steroids for 3 days) were seeded in 24-well plates at a density of approximately $4 \times 10^{4}$ with about $8 \times 10^{4}$ cells per well respectively in DCC medium. The following day, the cells were transfected by lipofectin (Invitrogen, UK) with $0.25 \mu \mathrm{g}$ ERE luciferase reporter construct (EREIItkluc) or activator protein-1 (AP-1) reporter construct (coll $\Delta 73$-luc), kindly supplied by $\mathrm{Dr}$ Paul Webb, University of California, San Francisco, CA, USA) and $0.25 \mu \mathrm{g} \beta$-galactosidase for normalising luciferase data (pCH110) for $4 \mathrm{~h}$. The cells were subsequently fed with DCC medium and left to recover overnight, before treatment with the appropriate concentration of E2, TAM, ICI or vehicle. In the case of AP-1 studies, cells were stimulated with tetradecanoyl phorbol acetate (TPA) as an internal control to monitor AP-1 activity. After treatment for $24 \mathrm{~h}$, the luciferase (Promega, UK) and $\beta$-galactosidase (GalactoStar; Applied Biosystems, UK) activity were measured using a luminometer.

\section{Effect of E2, TAM and ICI on ER and IGF signalling}

Wt MCF-7 cells (which had previously been stripped of steroids for 3 days by culturing in DCC medium) and LTED cells were seeded at a density of $5 \times 10^{5}$ cells per $25 \mathrm{~cm}^{2}$ culture flat. The following day, monolayers were washed once with phosphate-buffered saline (PBS) then replaced with DCC medium and increasing doses of E2, TAM, ICI or vehicle. The medium was changed daily over 6 days prior to harvesting the monolayers for analysis as indicated in the figure legends.

\section{Preparation of whole cell extracts for immunoblots}

Cell monolayers were washed with ice-cold PBS then lysed in extraction buffer ( $1 \%$ (v/v) Triton X100, $10 \mathrm{mM}$ Tris- $\mathrm{HCl}, \mathrm{pH} 7.4,5 \mathrm{mM}$ EDTA, $50 \mathrm{mM} \mathrm{NaCl}$, $50 \mathrm{mM}$ sodium fluoride, $2 \mathrm{mM} \mathrm{Na}_{3} \mathrm{VO}_{4}$ and 1 tablet of complete inhibitor mix (Roche; per $10 \mathrm{ml}$ buffer) and homogenised by passage through a 26 -gauge needle six times. The lysate was incubated on ice for $10 \mathrm{~min}$ then clarified by centrifugation $\left(14000 \mathrm{~g}\right.$ for $10 \mathrm{~min}$ at $\left.4^{\circ} \mathrm{C}\right)$. The protein concentration was then quantified using BioRad protein assay kit (BioRad, UK). Equal amounts of protein $(50 \mu \mathrm{g})$ were resolved by SDS-PAGE and transferred to nitrocellulose filters (Schleicher and Schuell, London, UK). Filters were blocked $(10 \mathrm{mM}$ Tris- $\mathrm{HCl}, \mathrm{pH} 8.3$ and $150 \mathrm{mM} \mathrm{NaCl}$ containing 4\% milk powder), washed twice in PBS containing $0.025 \%$ Tween-20 and probed with specific antibodies. The antibodies were diluted in $1.5 \%$ bovine serum albumin, $10 \mathrm{mM}$ Tris- $\mathrm{HCl}$, pH 8.3, $150 \mathrm{mM}$ $\mathrm{NaCl}, 0.025 \%$ Tween-20 and $0.01 \%$ sodium azide. Immuno complexes were detected using UltraSignal chemiluminescence kit from Pierce (Chester, Cheshire, UK). Chemiluminescence was quantified using Fluro-S and analysed using Quantity One software (BioRad).

\section{Results}

\section{Growth of Wt MCF-7 and LTED cells in response to E2, TAM and $\mathrm{ICl}$ with or without added insulin}

Evidence suggests that insulin and IGFs are potent breast cancer cell mitogens able to act synergistically with E2 (Stewart et al. 1990b). Studies have also shown that although IGF-IR has a 70-fold lower affinity for insulin compared with IGF-I, high doses of insulin can directly activate IGF-IR (Smith et al. 1988). Since the Wt MCF-7 and LTED cells were maintained in medium containing high concentrations of insulin and we had previously demonstrated the LTED cells had a twofold higher expression level of IGF-IR compared with Wt MCF-7 cells (Martin et al. 2003), we examined whether removal of insulin would affect the growth rate of the two cell lines in the presence of escalating doses of E2, TAM and ICI. E2 stimulated the proliferation of Wt MCF-7 cells in a dose-dependent manner both in the presence and the absence of insulin, with maximum growth occurring at $10^{-9} \mathrm{M}$ in both settings (Fig. 1A and B). In contrast, there was no growth stimulation by E2 in LTED cells in the presence of insulin, but a significant growth inhibition by E2 at concentrations $>10^{-10} \mathrm{M}$ (Fig. 1C). As previously reported, the baseline growth of the LTED cells in the absence of added E2 was tenfold higher than wt cells (data not show). In the absence of insulin, LTED cells revealed a persistent hypersensitivity to E2, being maximally stimulated at concentrations of E2 as low as $10^{-13} \mathrm{M}$ (Fig. 1D).

In Wt MCF-7 cells, TAM alone at maximal concentration $\left(10^{-6} \mathrm{M}\right)$ caused a slight, but significant, enhancement of proliferation in the presence and absence of insulin (Fig. 1A and B). There was no significant growth inhibition by ICI (in the absence of exogenous E2) in Wt MCF-7 cells plus or minus insulin. In LTED cells plus or minus insulin, TAM had no inhibitory or stimulatory effects, except at the highest concentration $\left(10^{-6} \mathrm{M}\right)$ where some growth inhibition 
Wt-MCF7 cells

+ insulin

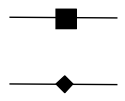

WT (+ins E2)

WT (+ins TAM)

A $\quad-$ WT (+ins ICI)

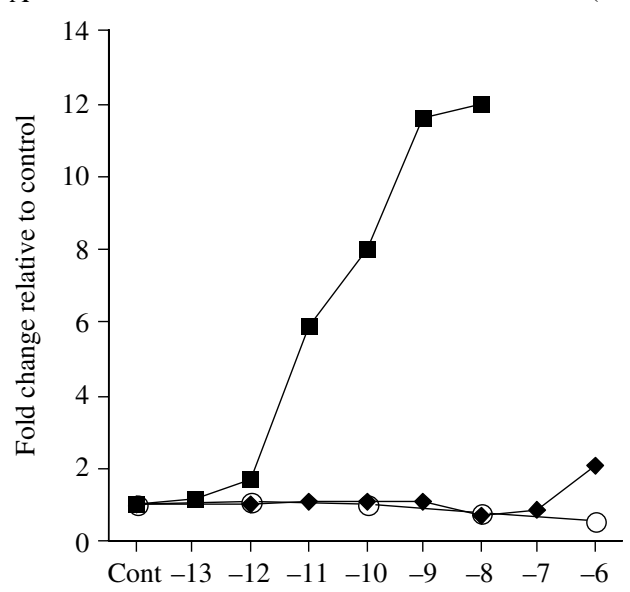

Drug concentration $(\log 10)(\mathrm{M})$

LTED cells

+ insulin

C
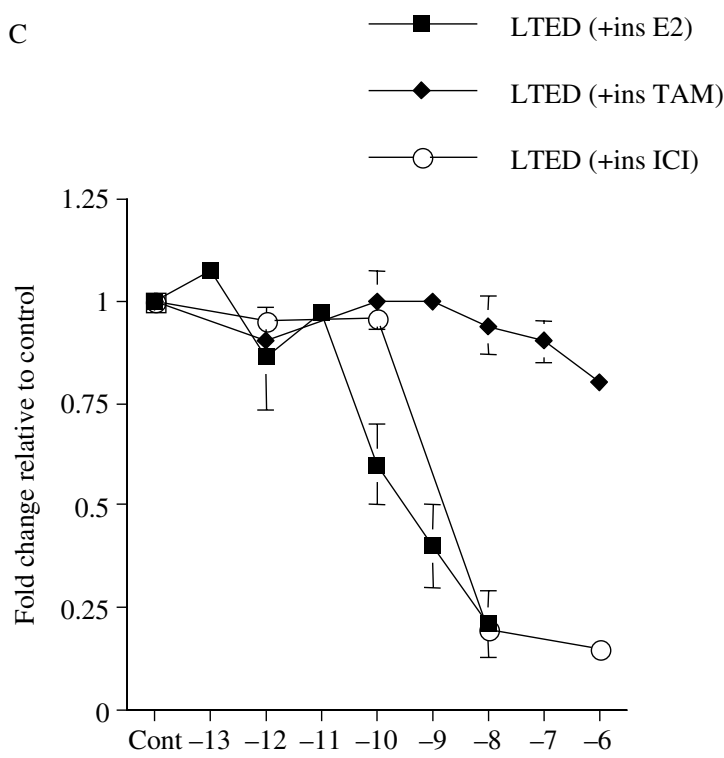

Drug concentration $(\log 10)(\mathrm{M})$
- insulin

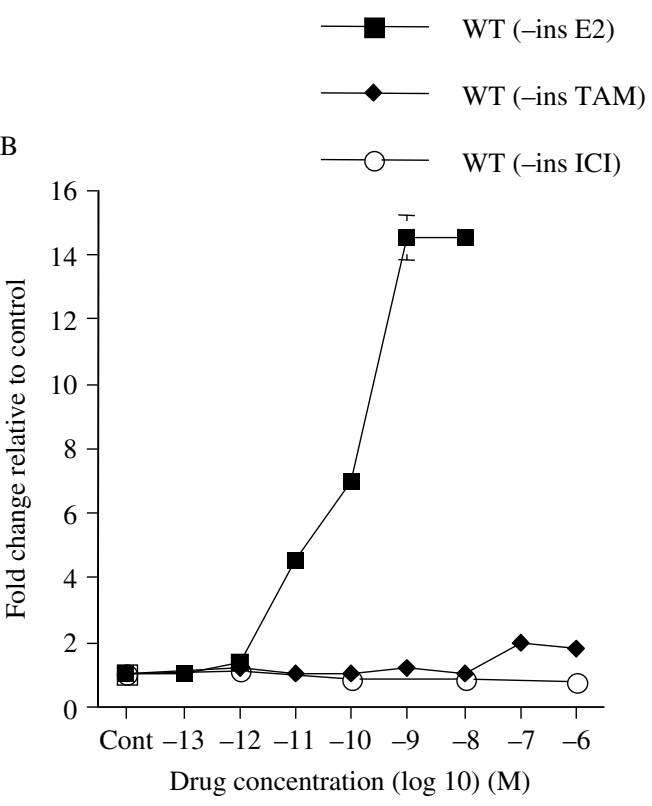

- insulin

$\mathrm{D}$

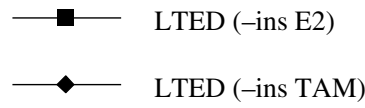

$\longrightarrow$ LTED (-ins ICI)

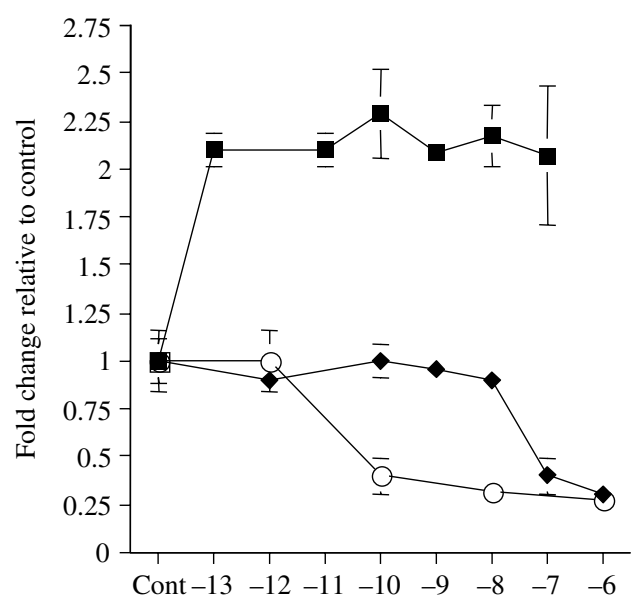

Drug concentration $(\log 10)(\mathrm{M})$

Figure 1 Growth response of wt (Wt) MCF-7 and LTED cells to E2 and anti-oestrogens. Wt MCF-7 and LTED cells were seeded into 12-well plates and treated with a $\log 7\left(10^{-13} \mathrm{M}\right.$ to $\left.10^{-6} \mathrm{M}\right)$ dose range of $\mathrm{E} 2, \mathrm{TAM}, \mathrm{ICl}$ or vehicle $(0.1 \%$ ethanol) for 6 days. ( $A$ and $C$ ) In the presence of $10 \mu \mathrm{g} / \mathrm{ml}$ insulin (ins) compared with (B and D) in the absence of insulin. The data represent the average of triplicate readings expressed as fold change relative to the vehicle treated control in each case. The means \pm S.E. are shown. Data were confirmed in three independent experiments.

Cont, control. 
of approximately $50 \%$ was observed in the absence of insulin (Fig. 1C and D). In contrast, ICI significantly inhibited the cell growth of LTED cells in a dosedependent manner to approximately $70 \%$ of the control. This effect of ICI in LTED cells was seen both with and without insulin (Fig. 1C and D).

\section{LTED cells were sensitive to the anti-proliferative effects of the pure anti-oestrogen $\mathrm{ICl}$ and could be rescued by the addition of E2}

To further characterise the sensitivity of the LTED cells to ICI, we compared their growth profile in the presence of increasing doses of ICI alone, versus Wt MCF-7 cells treated similarly but in the presence of a standard dose of E2 $\left(10^{-9} \mathrm{M}\right)$. Both cell lines revealed similar profiles with $\mathrm{IC}_{50}$ values of approximately $10^{-9} \mathrm{M}$ and $5 \times 10^{-9} \mathrm{M}$ respectively (Fig. 2A). These data were consistent with the hypothesis that the LTED cells remain ligand dependent and hypersensitive to residual E2 in the DCC medium. Nonetheless, studies have suggested that ICI may influence proliferation by directly inhibiting growth factor-mediated signalling (Huynh et al. 1996a). If this were the case, E2 would be unable to reverse the inhibitory effect of ICI in the LTED cells. To test this hypothesis, LTED and $\mathrm{Wt}$ MCF-7 cells were cultured in the presence of a standard dose of $10^{-9} \mathrm{M}, 10^{-8} \mathrm{M}$ or $10^{-7} \mathrm{M}$ ICI (demonstrated to inhibit cell growth) and increasing concentrations of E2 (Fig. 2B and C). Doses in excess of $10^{-11} \mathrm{M}$ E2 reversed the inhibitory effect of $10^{-9} \mathrm{M}$ ICI in the LTED cells (maximum stimulation $10^{-10} \mathrm{M}$ ) whilst in the Wt MCF-7 cells a dose of $10^{-10} \mathrm{M}$ E2 was required (maximum stimulation $10^{-9} \mathrm{M}$ ). Most noteworthy, doses in excess of $10^{-10} \mathrm{M}$ E2 were inhibitory in the LTED cells. In the presence of $10^{-8} \mathrm{M}$ ICI, similar doses of E2 were required to rescue the inhibitory effect of ICI in both the Wt MCF-7 and LTED cells. However, a full $\log 2$ increase in E2 was necessary to rescue the $\mathrm{Wt}$ MCF-7 cells treated with $10^{-7} \mathrm{M}$ ICI compared with a single log increase for the LTED.

\section{The pure anti-oestrogen $\mathrm{ICI}$ revealed the hypersensitive phenotype of the LTED cells}

In an attempt to further reveal the hypersensitive nature of the LTED cells, a similar set of experiments in which LTED cells were treated with a standard dose of E2 $\left(10^{-9} \mathrm{M}\right)$ and escalating doses of ICI (Fig. 3A) was carried out. E2 $\left(10^{-9} \mathrm{M}\right)$ alone inhibited LTED cell growth $50 \%$ compared with the DCC control as noted previously (Fig. 1C); however, this inhibition was reversed by increasing doses of ICI with cell proliferation restored almost to control levels by $10^{-8} \mathrm{M}$ ICI. Doses in excess of $10^{-7} \mathrm{M}$ ICI once again inhibited LTED cell proliferation in accordance with our previous findings. To test this further, a reverse experiment was carried out in which the LTED cells were treated with a standard dose of ICI $\left(10^{-9} \mathrm{M}\right)$ plus or minus insulin and increasing doses of either E2 or TAM (Fig. 3B-E) and their proliferation profile was compared with Wt MCF-7 cells treated with escalating doses of E2 or TAM plus or minus insulin but in the absence of ICI. In the presence of insulin and ICI $\left(10^{-9} \mathrm{M}\right)$, the inhibitory effect of E2 was reversed in the LTED cells (Fig. 3B) with maximum proliferation evident at $10^{-10} \mathrm{M}$ E2 whilst doses in excess of $10^{-9} \mathrm{M}$ E2 were now required to decrease proliferation by $50 \%$ (as opposed to $10^{-10} \mathrm{M}$ in the absence of ICI; see Fig. 1C). In the absence of insulin, however, the LTED cells showed a similar proliferation profile to Wt MCF7 cells with maximum growth occurring at $10^{-9} \mathrm{M}$ E2 (Fig. 3C). Most notably, treatment of the LTED cells with increasing doses of TAM in the presence of $10^{-9} \mathrm{M}$ ICI (plus or minus insulin) revealed the agonist effect of TAM, in keeping with the responses seen in the Wt MCF-7 cells (Fig. 3D and E). The ability of ICI to reverse the inhibitory effect of $\mathrm{E} 2$ is indicative of the hypersensitivity of the LTED cells and provides further evidence of their ligand-dependent nature. We postulate that in this setting ICI reduces the amount of ER to similar levels as those seen in wt cells and hence reveals the stimulatory effect of E2 and agonist activity of TAM. Taken together, these data suggested that the LTED cell proliferation was mediated wholly or in part via the ER/ERE pathway.

\section{High doses of E2 resulted in enhanced apoptosis in LTED cells}

As demonstrated in Fig. 1C, E2 doses in excess of $10^{-10} \mathrm{M}$ caused a marked decrease in the proliferation of the LTED cells. Previous studies have suggested that high doses of E2 can result in increased apoptosis (Song et al. 2001, 2005, Liu et al. 2003, Osipo et al. 2003, Lewis et al. 2005). To investigate the possibility that this was responsible for the decrease in cell proliferation noted in this setting, LTED and $\mathrm{Wt}$ MCF-7 cells were treated with or without $10^{-10} \mathrm{M}$ E2 for $72 \mathrm{~h}$ in the presence of insulin and the number of apoptotic cells determined. Although E2 appeared to have little effect on the Wt MCF-7 (Fig. 4), there was a threefold increase in apoptosis in the LTED cells. 


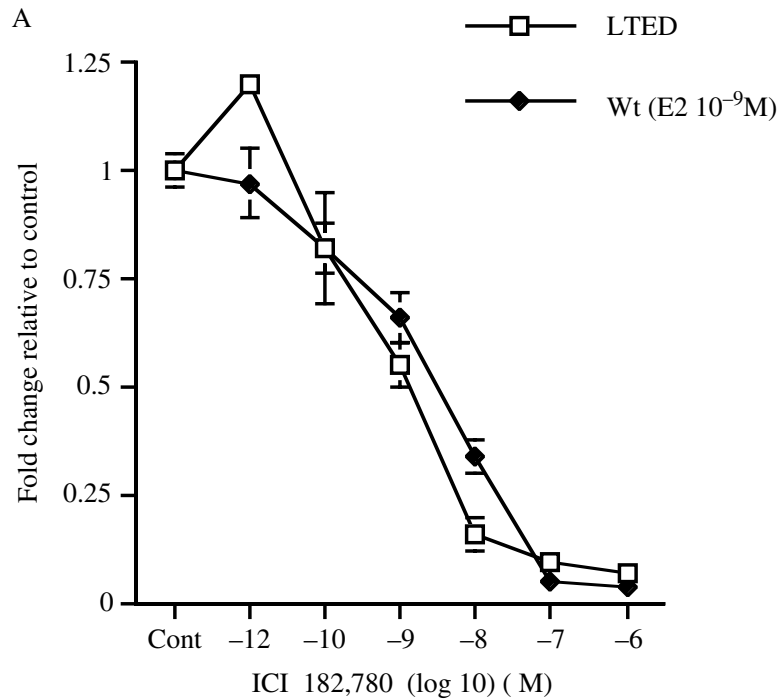

B

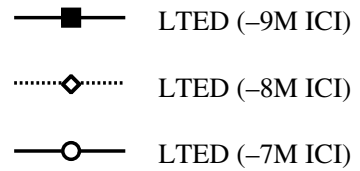

C
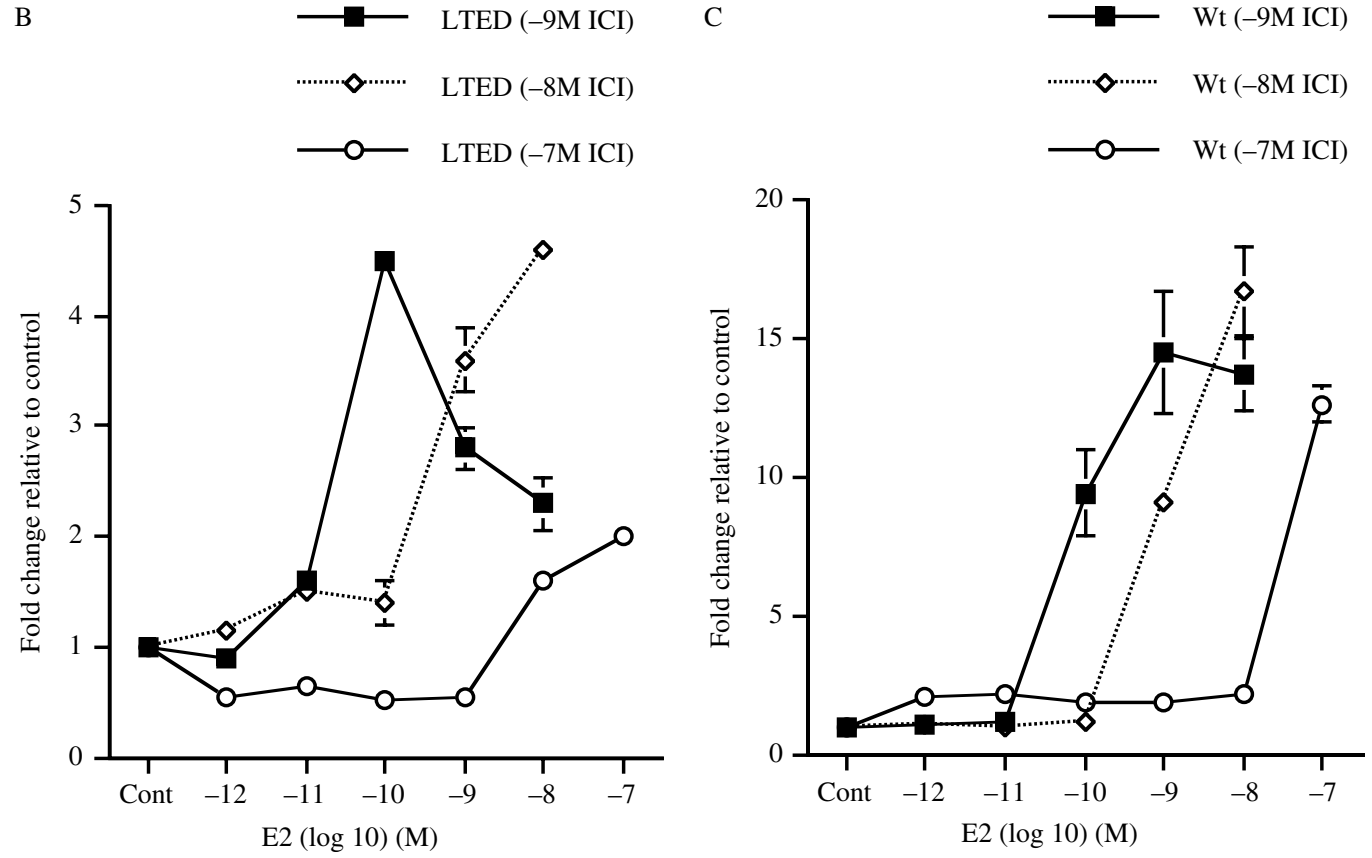

Figure 2 The pure anti-oestrogen $\mathrm{ICl}$ inhibits LTED cell growth but can be rescued by E2. (A) Cell growth assays were performed as described in the Materials and Methods. LTED and Wt MCF-7 cells were cultured in the presence of increasing doses of $\mathrm{ICl}$ alone or, in the case of Wt MCF-7 cells, in combination with $10^{-9} \mathrm{M} \mathrm{E2}$. Cells were incubated for 6 days. The data represent the average of triplicate readings. The means \pm S.E. are shown. (B and C) Wt MCF-7 and LTED cells were cultured as previously described in the presence of $10^{-9} \mathrm{M}(-9 \mathrm{M}), 10^{-8} \mathrm{M}(-8 \mathrm{M})$ or $10^{-7} \mathrm{M}(-7 \mathrm{M}) \mathrm{ICl}$ and increasing doses of E2. The data represent the average of triplicate readings. The means \pm S.E. are shown. Data were confirmed in two independent experiments.

\section{LTED appeared to use the classical ER/ERE pathway for proliferation and transcription}

The proliferation data depicted in Figs 1 and 2 suggested that the LTED cells used the classical ER/ERE pathway for proliferation and transcription. To test this further, the level of five endogenous genes known to be responsive to $\mathrm{E} 2$ were screened by quantitative real-time RT-PCR. Both LTED and Wt MCF-7 cells were treated with escalating doses of E2 for $24 \mathrm{~h}$ in the 


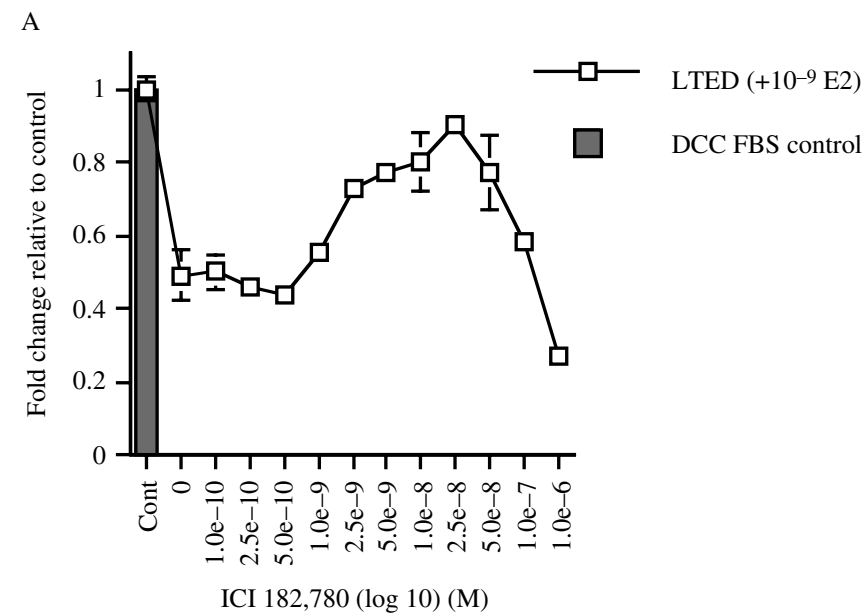

B

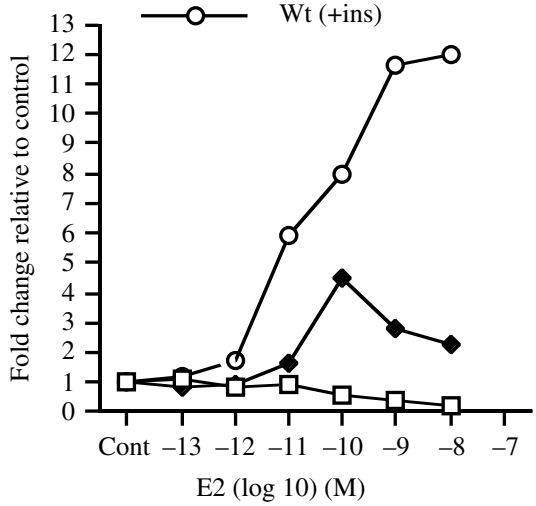

$\mathrm{D}$

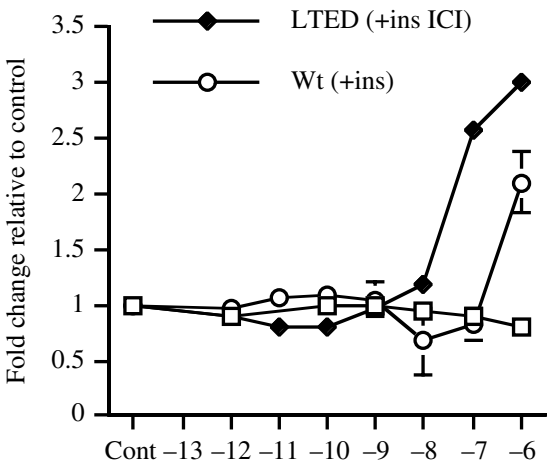

TAM $(\log 10)(\mathrm{M})$
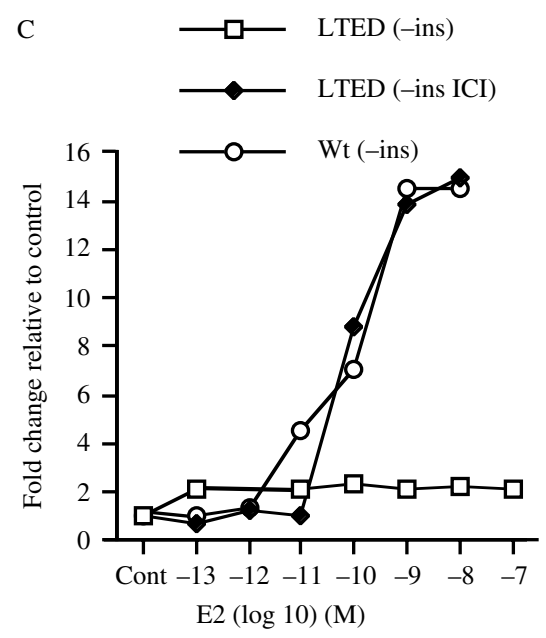

E $\square-\operatorname{LTED}(-\mathrm{ins})$

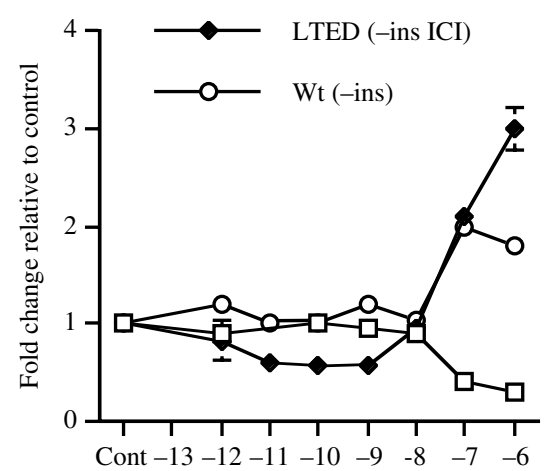

TAM $(\log 10)(M)$

Figure 3 The pure anti-oestrogen ICI reveals the hypersensitive phenotype of the LTED cells. (A) Addition of ICI reduced the anti-proliferative effects of E2. LTED cells were cultured as previously described in the presence of $10^{-9} \mathrm{M} \mathrm{E2}$ and increasing doses of ICl. The data represent the average of triplicate readings. The means \pm S.E. are shown. (B and $\mathrm{C}) \mathrm{Addition}$ of $\mathrm{ICI}$ reveals the hypersensitivity of the LTED cells to E2. LTED cells were cultured with or without insulin (ins) in the presence or absence of $10^{-9} \mathrm{M} \mathrm{ICl}$ and increasing doses of E2. Wt MCF-7 cells were treated similarly but in the absence of ICl. The data represent the average of triplicate readings. The means \pm S.E. are shown. ( $D$ and $E$ ) Addition of $I C I$ reveals the agonist activity 


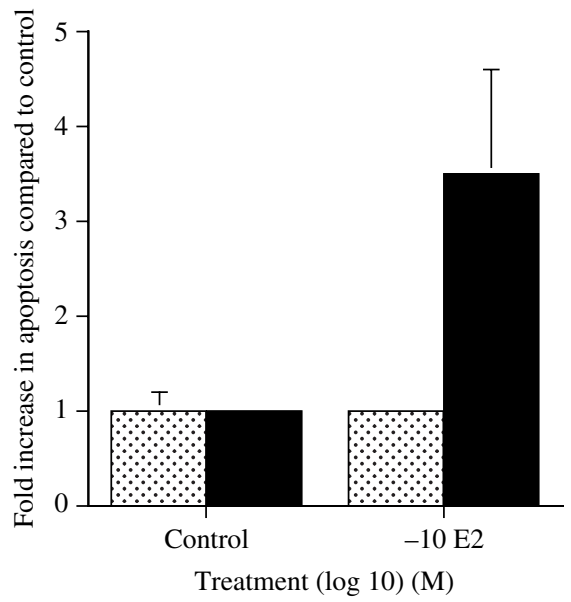

Figure 4 High doses of E2 result in enhanced apoptosis in LTED cells. LTED (solid bars) and Wt MCF-7 (dotted bars) cells were cultured in DCC medium plus or minus $10^{-10} \mathrm{M}$ E2 $(-10$ E2) for $72 \mathrm{~h}$. The number of apoptotic cells was determined using a cell death detection ELISA. The data represent the average of duplicate readings. The means \pm S.E. are shown. Data were confirmed in two independent experiments.

presence of insulin. RNA was extracted from the cell lines and the levels of expression of ER, PR, cathepsin $\mathrm{D}, \mathrm{c}-\mathrm{myc}$ and $\mathrm{pS} 2$ were measured. Treatment with E2 resulted in a largely dose-dependent decrease in ER (Fig. 5) in both Wt MCF-7 and LTED cells. However, in the LTED cells, doses as low as $10^{-13} \mathrm{M}$ caused a $50 \%$ decrease in ER mRNA whilst having no effect on the Wt MCF-7 cell line. Treatment with $10^{-8} \mathrm{M}$ E2 caused an increase in ER mRNA expression in three independent experiments in both cell lines and as yet we have no explanation for this finding. Expression of pS2, cathespin D, c-myc and PR (Fig. 5) all increased in a dose-dependent manner in both cell lines in response to added E2.

To further assess the effects of ER/ERE activity in the LTED versus the Wt MCF-7, transient transfections with an ERE-linked luciferase reporter construct were carried out. The basal transcription activity within the Wt MCF-7 and LTED cells in the presence and absence of insulin was monitored. As we have documented previously (Martin et al. 2003) there was an approximate tenfold increase in ER transcriptional activity in LTED compared with Wt MCF-7 cells. This was observed to a similar extent with or without added insulin (Fig. 6A).
A dose-dependent increase in ER-mediated transcription was observed with E2 both in Wt MCF-7 and LTED cells (Fig. 6B). The increase in response to E2 was approximately 20 -fold over control for both the Wt MCF-7 and LTED cells. However, as shown in Fig. 6A, LTED cells started with a significant increase in basal transcriptional activity compared with Wt cells. Thus for $10^{-13} \mathrm{M}$ E2 the LTED cells transcription is approximately tenfold higher than the Wt MCF-7 cells in absolute terms. It should be noted that while it is reasonable to describe this response to low doses of E2 as hypersensitive it does not comply with the strict definition of a significantly reduced dose required to achieve $50 \%$ maximal stimulation. Analysis of the effect of insulin on transcriptional activity in response to E2 revealed no difference in Wt or LTED cells plus or minus insulin (data not shown).

In Wt MCF-7 cells (in the absence of added E2), TAM alone caused no significant stimulation or inhibition of ER transcriptional activity (Fig. 6C) and was independent of insulin (data not shown). Although TAM had a partial agonist effect on the growth of Wt cells at high concentrations $\left(10^{-6} \mathrm{M}\right)$, no such effect on the ER $\alpha$ transactivation was seen (Fig. 6C). Likewise, in Wt MCF-7 cells, ICI (in the absence of added E2) had no inhibitory effect on ER $\alpha$ transactivation (Fig. 6D). As such, these transcriptional results with both anti-oestrogens broadly mirrored the effects seen in cell growth assays (Fig. 1).

In LTED cells, TAM had no effect on ER $\alpha$ transactivation (Fig. 6C). In contrast, ICI significantly inhibited (by $>90 \%$ ) the transcriptional activity of ER in a dose-dependent manner (Fig. 6D). Again this inhibitory effect of ICI in LTED cells was seen both in the presence and the absence of insulin (data not shown) and mirrored the growth-inhibitory effects seen with ICI.

We next investigated the ability of ICI to antagonise E2-stimulated transcription in both Wt MCF-7 and LTED cells. In the presence of a standard dose of $10^{-9} \mathrm{M}$ E2 and increasing doses of ICI, the Wt MCF-7 cells were inhibited by ICI in a dose-dependent manner and showed a similar ER $\alpha$ transactivation profile to the LTED cells treated with ICI in the absence of E2 (compare Fig. 6D with 6E). In the presence of a standard dose of E2, the LTED cells showed a reduced sensitivity to ICI compared with the Wt cells (Fig. 6E). This, combined with our previous cell growth data, suggests that elevated levels of ER and the resultant

of TAM in LTED cells. LTED cells were cultured with or without insulin in the presence or absence of $10^{-9} \mathrm{M} \mathrm{ICl}$ and increasing doses of TAM. Wt MCF-7 cells were treated similarly but in the absence of ICl. The data represent the average of triplicate readings. The means \pm S.E. are shown. All data were confirmed in three independent experiments. 

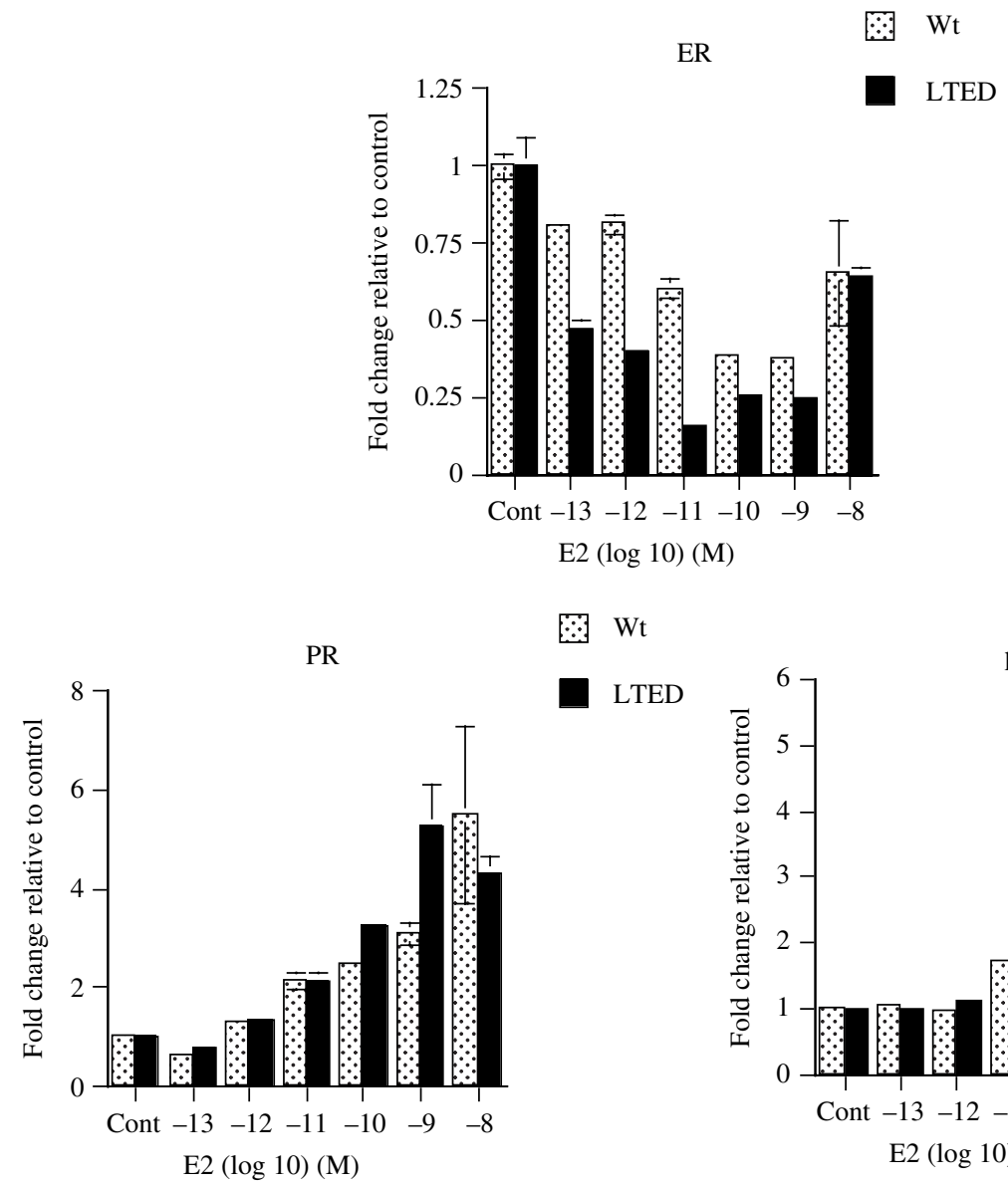

$\mathrm{Wt}$

LTED
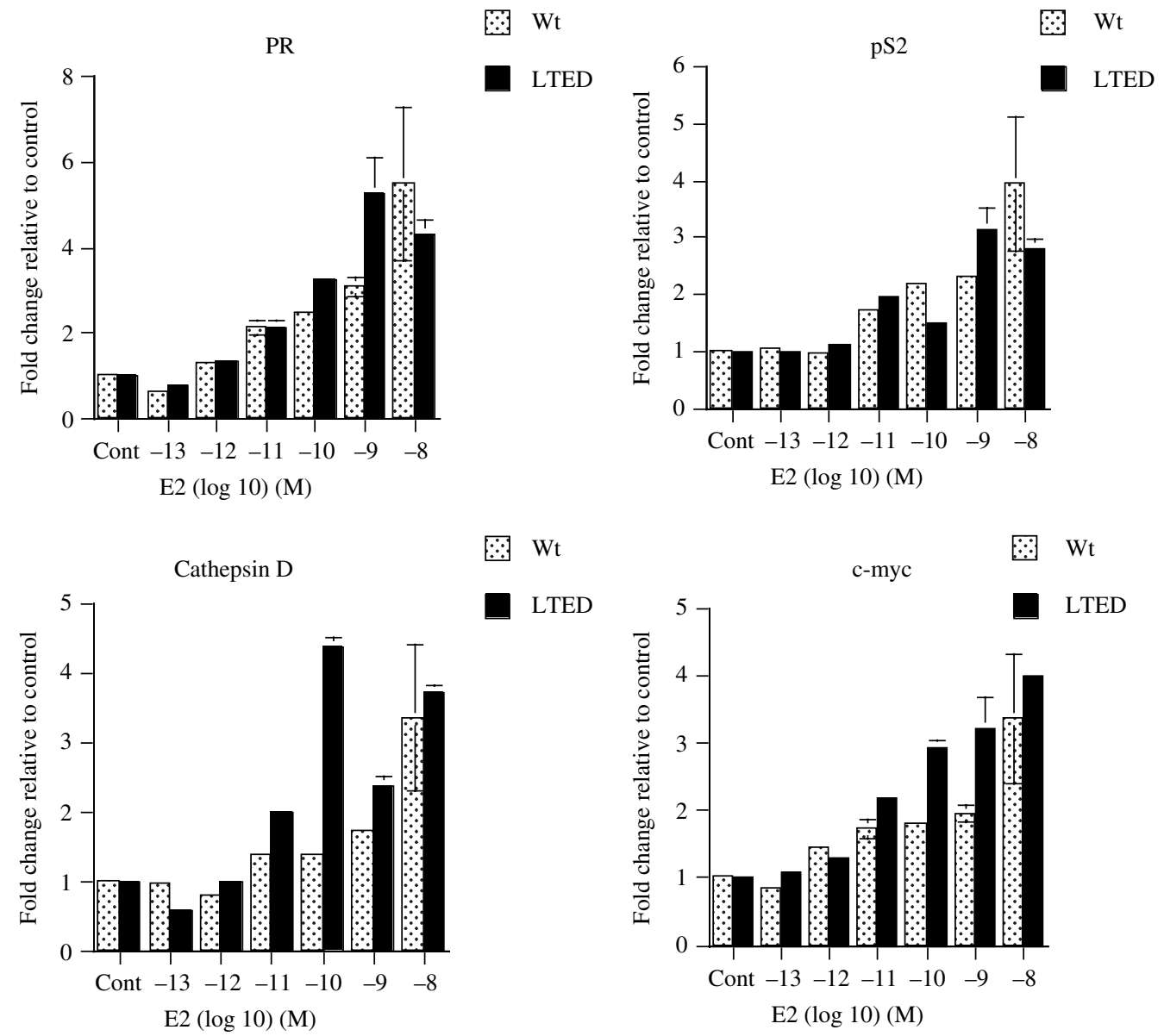

Wt

LTED

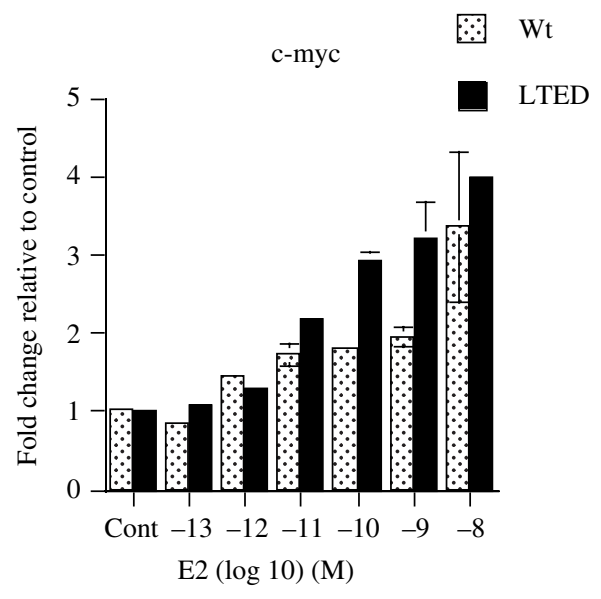

Figure 5 LTED appear to use the classical ER/ERE pathway for proliferation and transcription. LTED and Wt MCF-7 were cultured in the presence of DCC medium containing insulin and plus or minus increasing doses of E2. The level of expression of five endogenous E2 responsive genes was measured by quantitative real-time RT-PCR. The data represent the average of triplicate samples. The means \pm S.E. are shown. The data were confirmed in three independent experiments. 
ER-driven transcription are important components of the LTED cell phenotype.

\section{LTED did not appear to use non-classical AP-1 pathways as part of their adaptive mechanism}

Recent studies have suggested that resistance to endocrine therapies may involve the non-classical interaction of ER with the Fos/Jun (AP-1) complex, allowing the ER to exert its action by binding indirectly to AP-1 sites in target genes influencing proliferation and cell survival (Webb et al. 1999, Shaulian \& Karin 2001, DeNardo et al. 2005). To determine if AP-1 played a role in the LTED phenotype, Wt MCF-7 and LTED cells were transfected with an AP-1 luciferase reporter construct followed by exposure to TPA and increasing doses of E2, TAM or ICI (Fig. 7). Assessment of the basal AP-1 activity in the LTED versus the Wt MCF-7 cells showed markedly less activity in the LTED cell line (approximately $50 \%$ in the presence of insulin and approximately $70 \%$ less in the absence of insulin) compared with the parental cell line (Fig. 7A). TPA caused a twofold increase in AP-1 transactivation as expected. However, none of the other endocrine agents revealed any effect (Fig. 7B-D) plus or minus insulin (data minus insulin not shown). This suggested that AP-1 did not play a major role in this setting.

\section{Expression of ER $\alpha$, ER $\beta$, IGF-IR, IRS-1 and IRS-2 in Wt MCF-7 and LTED cells}

The basal level of expression of ER $\alpha, E R \beta$ and components of the IGF signalling pathway in $\mathrm{Wt}$ MCF-7 and LTED cells was assessed in untreated cells growing in their maintenance medium. In LTED cells, expression of ER $\beta$ and IRS- 1 were similar to the $\mathrm{Wt}$ cells, whilst levels of ER $\alpha$, IRS-2 and IGF-IR protein were all significantly increased (Fig. 8).

\section{Effect of E2, TAM and ICI on expression of $E R \alpha$ and ER $\beta$ in Wt MCF-7 and LTED cells}

To investigate the basis by which ICI, but not TAM, can inhibit both the cell growth and the transcriptional activity of the LTED cells (with insulin), both Wt MCF-7 and LTED cells were treated for 6 days in the presence of increasing doses of E2, TAM or ICI plus insulin. Western blots of whole cell extracts were probed for ER $\alpha$ and ER $\beta$ expression. ICI (in the absence of E2) down-regulated ER $\alpha$ protein expression in a dose-dependent manner, both in $\mathrm{Wt}$ and
LTED cell lines. It is noteworthy that higher doses of ICI were necessary to reduce ER $\alpha$ levels in the LTED compared with Wt MCF-7 $\left(10^{-8} \mathrm{M}\right.$ versus $\left.10^{-10} \mathrm{M}\right)$ (Fig. 9A and B). ICI had no effect on ER $\beta$ expression in either Wt or LTED cells and to our knowledge this is the first time this observation has been reported. There was no effect of TAM on expression of ER $\alpha$ or ER $\beta$ in either cell type (compare Fig. 9A with 9B). E2 had a dose-dependent inhibitory effect on ER $\alpha$ expression in the Wt cells and most markedly in the LTED cells where doses in excess of $10^{-9} \mathrm{M}$ resulted in complete loss of ER $\alpha$ (Fig. 9A).

\section{Effect of E2, TAM and ICI on expression of IGF signalling components in Wt MCF-7 and LTED cells}

Addition of E2 resulted in an increase in IGF-IR expression in both $\mathrm{Wt} \mathrm{MCF-7} \mathrm{and} \mathrm{LTED} \mathrm{cells}$ particularly at doses in excess of $10^{-9} \mathrm{M}$ (Fig. 9A and B). IRS- 1 decreased in the LTED cells whilst IRS2 remained unchanged. Most notably, this decrease in IGF-IR signalling in the LTED cells coincides with high doses of E2, which we previously showed (Fig. 1) decreased proliferation and increased apoptosis (Fig. 4). Conversely, in the Wt MCF-7 cells, IRS-1 remained unchanged whilst IRS-2 expression was increased, in keeping with the stimulatory response to high doses of E2 and enhanced proliferation. TAM (in the absence of exogenous E2) had no appreciable effect on expression of IRS-1, IRS-2 or IGF-IR expression in Wt MCF-7 cells (Fig. 9B). Similarly, the LTED cells treated with TAM showed no significant changes in IRS-1 or IRS-2 expression. However, TAM doses in excess of approximately $10^{-7} \mathrm{M}$ had an inhibitory effect on IGF-IR expression in the LTED cells (Fig. 9A).

ICI (in the absence of added E2) had no effect on the expression of IRS-1, IRS-2 or IGF-IR in the Wt MCF7 cells. However, similar treatment of the LTED cells resulted in a dose-dependent decrease in the expression of IRS-1, IRS-2 and IGF-IR (Fig. 9A).

\section{Effect of TAM and ICI on expression of IGF signalling components in Wt MCF-7 in the presence of exogenous E2}

We hypothesised that in the absence of exogenous E2 the un-liganded ER within the Wt MCF-7 cells would be largely inactive and unable to drive ER/EREdirected transcription. As a consequence, although ICI would decrease ER $\alpha$ protein expression, its inhibitory effects on proliferation would be negligible. This view is supported by the lack of effect of ICI on IGF-IR 
A
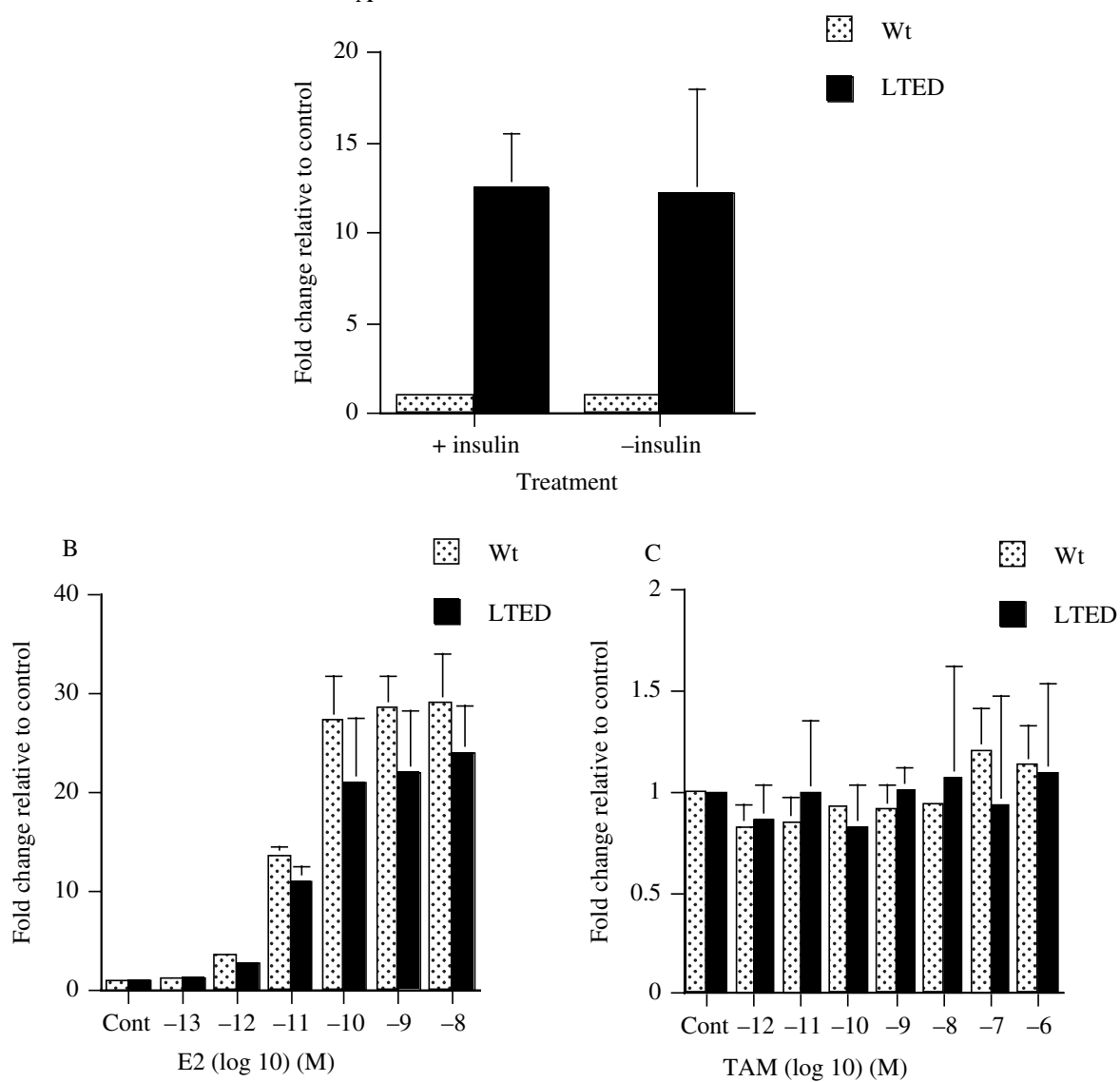

TAM $(\log 10)(\mathrm{M})$
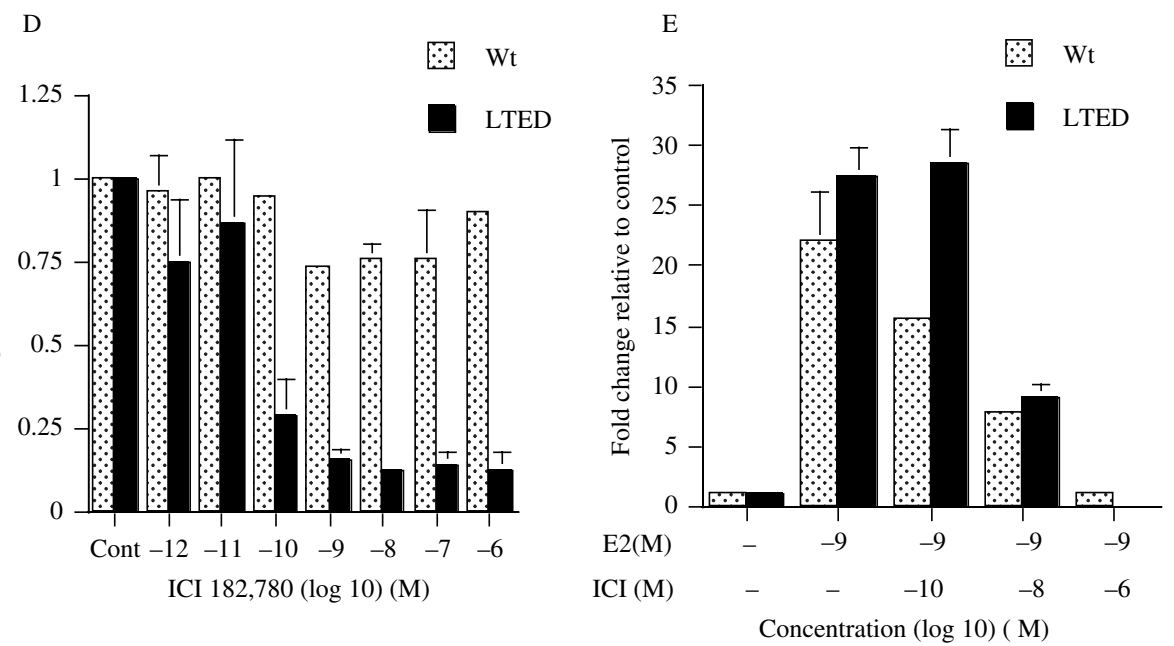

Figure 6 Effects of E2, TAM and ICI on transcriptional activity of an ERE-reporter gene in wt and LTED cells. (A) Basal ER-mediated transcription in the presence and absence of insulin. Cells were co-transfected with EREIItkluc and pCH110. After transfection, cells were treated with DCC medium plus or minus insulin for $24 \mathrm{~h}$. Cells were harvested and luciferase and $\beta$-galactosidase activities measured. To correct for differences in transfection efficiency, the luciferase activities were normalised to $\beta$-galactosidase activities. Normalised luciferase activity from triplicate wells was expressed relative to the $\mathrm{Wt}$ MCF-7 control. Bars represent \pm S.E. of the means. (B) The effect of E2 on ER-mediated transcription. Wt and LTED cells were transiently co-transfected with ERElltkluc and $\mathrm{pCH} 110$ in serum-free medium followed by 24-h incubation with DCC medium 
A

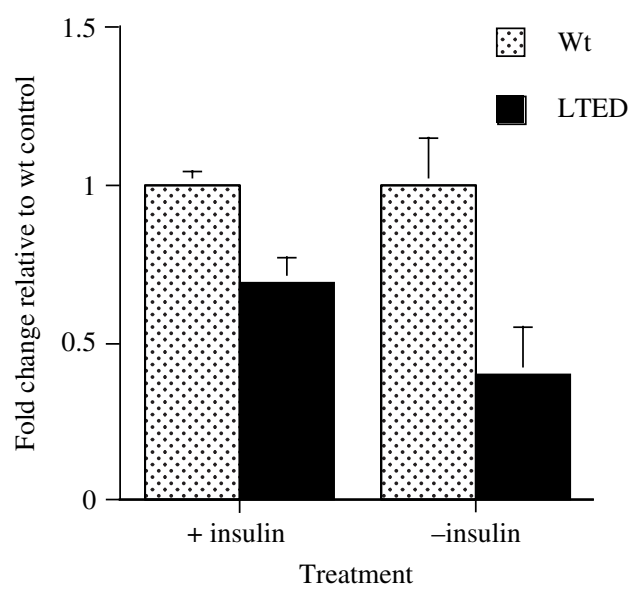

$\mathrm{C}$

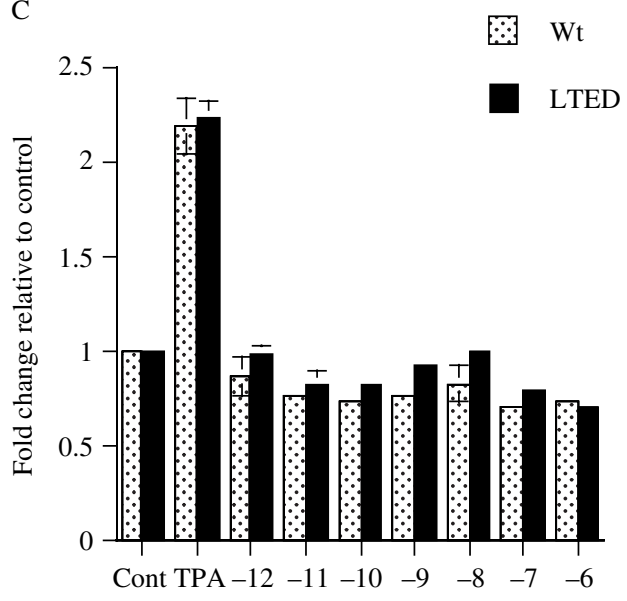

TAM $(\log 10)(\mathrm{M})$
B

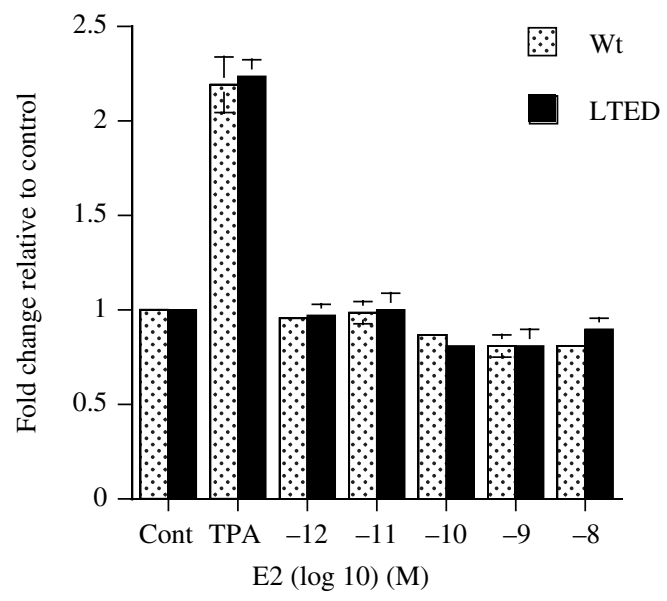

$\mathrm{D}$

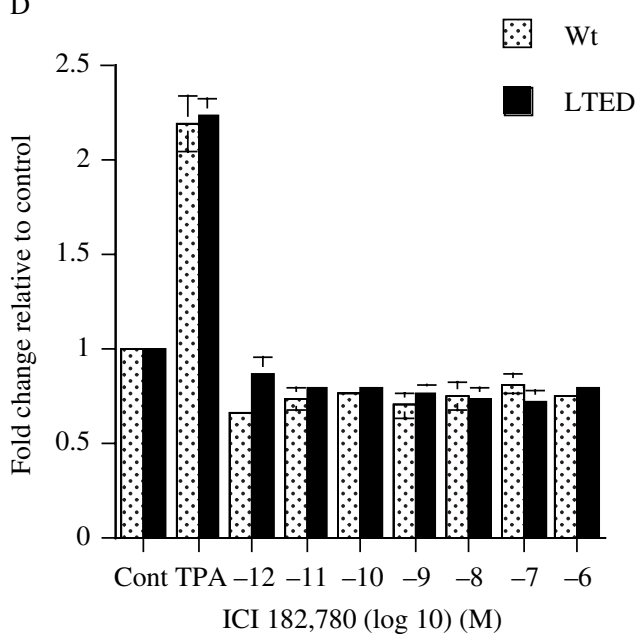

Figure 7 LTED cells do not appear to use non-classical AP-1 pathways as part of their adaptive mechanism. (A) Basal AP-1mediated transcription in the presence and absence of insulin. Cells were co-transfected with coll $\Delta 73$-luc and pCH110. After transfection, cells were treated with DCC FBS medium plus or minus insulin for $24 \mathrm{~h}$. Cells were harvested and luciferase and $\beta$ galactosidase activities measured. To correct for differences in transfection efficiency, the luciferase activities were normalised to $\beta$ galactosidase activities. Normalised luciferase activity from triplicate wells was expressed relative to the wt MCF-7 control. Bars represent \pm S.E. of the means. (B) LTED and Wt MCF-7 cells were co-transfected with coll $\Delta 73$-luc and pCH110. After transfection, cells were treated with $10^{-7} \mathrm{M}$ TPA or increasing doses of E2 for $24 \mathrm{~h}$. Cells were harvested and luciferase and $\beta$-galactosidase activities measured. The data are reported as the fold increase compared with vehicle-treated control. (C) The effect of TAM on AP1 -mediated transcription. Wt and LTED cells were treated for $24 \mathrm{~h}$ with DCC medium containing increasing doses of TAM in the absence of exogenous E2. (D) The effect of ICl on AP-1-mediated transcription. Wt and LTED cells were transfected as described previously followed by treatment for $24 \mathrm{~h}$ with increasing doses of $\mathrm{ICl}$ in the absence of exogenous $\mathrm{E} 2$. All data shown were normalised against the $\beta$-galactosidase control. Luciferase activity from triplicate wells was expressed relative to the vehicle-treated control. Bars represent \pm S.E. of the means. Results were confirmed in three independent experiments.

containing increasing doses of E2 plus or minus insulin (minus insulin data not shown). Normalised luciferase activity from triplicate wells was expressed relative to the vehicle-treated control. Bars represent \pm S.E. of the means. (C) TAM has no significant effect on Wt MCF-7 and LTED cells. Cell lines were transfected as described and treated for $24 \mathrm{~h}$ with increasing doses of TAM in the absence of exogenous E2. (D and E) ICl inhibits basal ER-mediated transcription in LTED cells compared with Wt MCF-7. Wt and LTED cells were transfected as described then treated for $24 \mathrm{~h}$ with increasing doses of ICI plus or minus E2. Normalised luciferase activity from triplicate wells was expressed relative to the vehicle-treated control. Bars represent \pm S.E. of the means. Results shown were confirmed in four independent experiments. 
Wt MCF-7 LTED

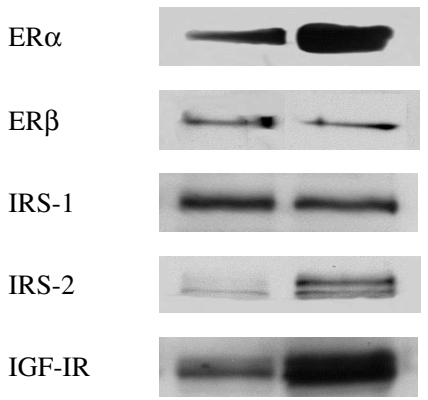

Figure 8 Basal expression of ERs (ER $\alpha$ and ER $\beta$ ), IGF-IR and IRS-1 and IRS-2 proteins in Wt MCF-7 and LTED cells. Cell lysates from Wt and LTED cells growing in their maintenance medium were resolved through $10 \%$ SDS-PAGE gels. Following western blotting, filters were subsequently probed with antibodies raised against ER $\alpha, E R \beta$, IGF-IR, IRS-1 and IRS-2.

expression. Conversely, in the LTED cells, our current data suggest that ER/ERE activity is enhanced by hypersensitivity to the residual E2 within the DCC medium. As a consequence, the inhibitory effects of ICI were apparent in both transcription and proliferation assays and supported by the concomitant decrease in ER $\alpha$ and IGF-IR expression. To support our view further, that the LTED cells were hypersensitive to E2 and that inhibition by ICI was a direct result of this, we treated Wt MCF-7 cells with a standard dose of E2 $\left(10^{-9} \mathrm{M}\right)$ and increasing doses of ICI and TAM in the presence of insulin (Fig. 9C). TAM had no effect on ER, IRS-1, IRS-2 or IGF-IR protein expression. However, increasing doses of ICI resulted in a decrease in ER, IRS-1, IRS-2 and IGF-IR expression, which was particularly marked at doses in excess of $10^{-8} \mathrm{M}$. When compared with the LTED cells (Fig. 9A) the profile was similar but in this case doses in excess of $10^{-9} \mathrm{M}$ resulted in almost complete loss of IGF-IR, confirming the hypersensitivity of the LTED cells.

\section{Discussion}

There is increasing evidence for adaptive changes in the hormone responsiveness of breast cancer cells during therapy with LTED with aromatase inhibitors. With the greater use of first-line LTED for most breast cancer patients who have ER-positive tumours (Nabholtz et al. 2000, Mouridsen et al. 2001, ATAC Trialists' Group 2002), an understanding of the mechanisms involved in resistance to this approach is of paramount importance for optimal patient care. It is clear that these cells often remain steroid receptor positive once they become refractory to LTED and that expression and activation of ER is significantly enhanced in these cells (Jeng et al. 1998, Chan et al. 2002, Martin et al. 2003). Some criticism of these models has been made based on recent findings that suggest that culture dishes used to maintain these cell lines contain oestrogenic substances which may contribute to the growth of these LTED cell lines (Ishikawa et al. 2001). However, several groups have documented hypersensitivity to low levels of E2 in LTED cells, with growth stimulation at concentrations as low as $10^{-13}$ M E2 (Masamura et al. 1995, Santen et al. 2001, Chan et al. 2002, Martin et al. 2003), less than the levels of residual E2 $\left(10^{-12} \mathrm{M}\right)$ detected in postmenopausal women receiving aromatase inhibitors (Geisler et al. 2002).

Here we have shown that removal of insulin appears to reveal a persistent hypersensitivity in the LTED cells, which is imperceptible in the presence of insulin, as the cells have reached their maximum growth rate. In fact, in the presence of insulin, doses of $E 2$ in excess of $10^{-10} \mathrm{M}$ (which provide a stimulatory effect in the Wt cells) are inhibitory to a similar level as ICI and resulted in enhanced apoptosis in the LTED versus the Wt MCF-7 cells. Previous studies have also reported the inhibitory effect of high doses of E2 and observed a concomitant increase in the expression of Fas ligand. As a consequence, it has been postulated that tumour regression in response to high doses of E2 may result via Fas-mediated apoptosis and that E2 significantly inhibits cell growth primarily through a proapoptotic action involving capase 7 and 9 (Song et al. 2001, 2005, Liu et al. 2003, Osipo et al. 2003, Lewis et al. 2005).

Overall, these data suggest that cross-talk between the IGF and steroid signalling pathways may be involved in the adaptation of the cells to E2 deprivation.

Although changes in the molecular cross-talk allowing adaptation to LTED appear complex (Coutts \& Murphy 1998, Jeng et al. 1998, Nicholson et al. 1999, Shim et al. 2000, Stephen et al. 2001, Chan et al. 2002, Martin et al. 2003) it is clear that ER signalling remains an integral part of this mechanism driving proliferation of these cells. Hence evaluating whether anti-oestrogens remain effective in this setting is of major importance.

We have previously demonstrated that LTED cells have a fourfold higher level of ER, which is phosphorylated on ser ${ }^{118}$ compared with the Wt cells. Phosphorylation of ER in the LTED setting remained ligand dependent, as evidenced by the fact that complete abrogation of $\mathrm{p} 42 / \mathrm{p} 44$ MAPK (shown to phosphorylate ER $\operatorname{ser}^{118}$ in a ligand-independent 
A LTED

B $\quad$ Wt MCF-7

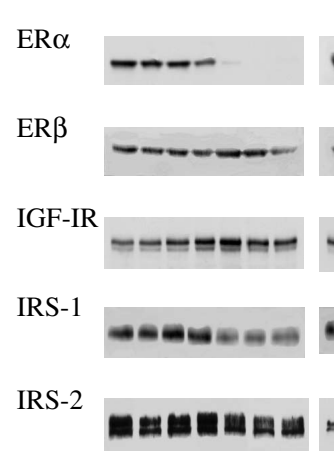

+ insulin
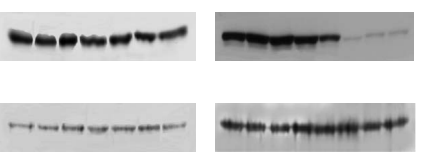

ヘーーーーー

\section{exane}

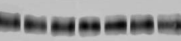

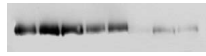

แะะะที

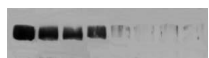

+ insulin
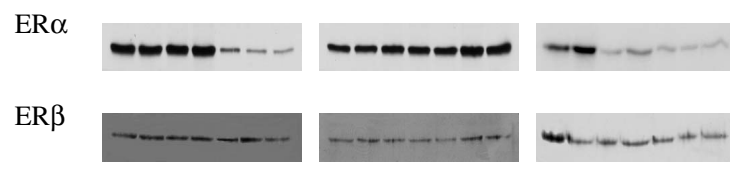

IGF-IR
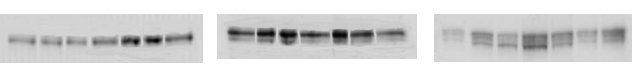

IRS-1
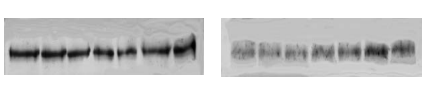

IRS-2

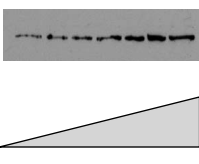

E2

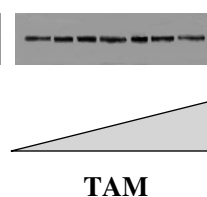

TAM

+ insulin

$\mathrm{ER} \alpha$

IGF-IR

IRS-1

IRS-2
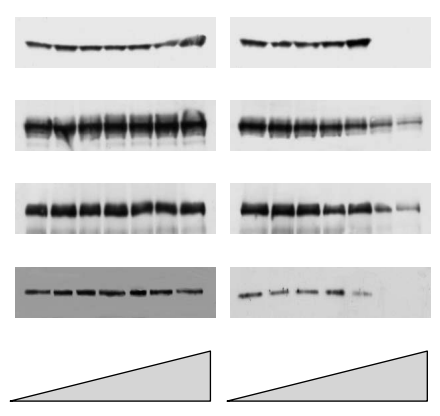

TAM
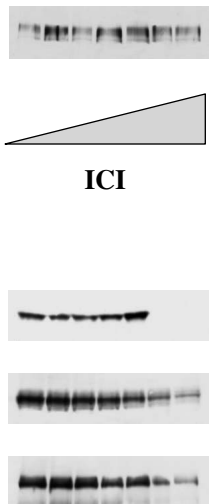

ICI

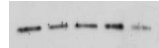

$-\cdots$

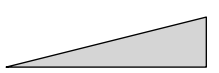

ICI

Figure 9 Effect of E2, TAM and ICl on expression of ERs (ER $\alpha$ and ER $\beta$ ), IGF-IR, IRS-1 and IRS-2 protein expression in Wt MCF-7 and LTED cells. Cells lysates prepared from wt and LTED cells treated for 6 days with increasing concentration of E2 (control $\left(0.1 \%(\mathrm{v} / \mathrm{v})\right.$ vehicle), $\left.10^{-13}, 10^{-12}, 10^{-11}, 10^{-10}, 10^{-9}, 10^{-8} \mathrm{M}\right)$, TAM (control $\left(0.1 \%(\mathrm{v} / \mathrm{v})\right.$ vehicle), $10^{-12}, 10^{-10}, 10^{-9}, 10^{-8}$, $\left.10^{-7},{ }^{-6} \mathrm{M}\right)$ or $\mathrm{ICl}$ (control $\left(0.1 \%(\mathrm{v} / \mathrm{v})\right.$ vehicle), $\left.10^{-12}, 10^{-11}, 10^{-9}, 10^{-8}, 10^{-7}, 10^{-6} \mathrm{M}\right)$ plus insulin were resolved through $10^{-}$ SDS-PAGE gels. Western blot analysis with antibodies raised against ER $\alpha$, ER $\beta$, IGF-IR, IRS-1 and IRS-2 was used to profile protein expression. Panels ( $A$ and $B$ ) show the effect of the treatments on LTED and Wt cells respectively. ICI and TAM treatments are in the absence of exogenous E2. (C) Wt MCF-7 cells in the presence of a standard dose of exogenous E2 $\left(10^{-9} \mathrm{M}\right)$ and increasing doses of TAM or ICI show similar signalling profile to LTED cells. Cells lysates were prepared from wt cells treated for 6 days as previously described but in the presence of exogenous E2 and insulin. Western blots show the effect on ER $\alpha$, ER $\beta$, IGF-IR, IRS-1 and IRS-2 expression in wt cells. The data shown in each panel are representative of two independent experiments. 
manner (Bunone et al. 1996)) had no effect on phosphorylation. We have postulated that the observed increase in basal transcription and E2 sensitivity may relate to the elevated level of activated ER (Martin et al. 2003).

The data in this study from transient transfection assays with an ERE-reporter gene similarly illustrate a significant increase in ER $\alpha$ transactivation in LTED cells compared with Wt cells (Fig. 3). It has been suggested that enhanced $\mathrm{p} 42 / \mathrm{p} 44$ MAPK signalling may be responsible for this sensitisation and activation of ER signalling in the LTED setting (Shim et al. 2000, Martin et al. 2003). More recently, we reported that enhanced ERBB2 expression and subsequent p42/p44 MAPK activation may be one of the key underlying adaptive changes in these cells (Martin et al. 2003). Other polypeptide growth factors may also be important in the growth regulation of breast cancer cells, including insulin and IGF (Stewart et al. 1990a, Ando et al. 1998). E2 can affect IGF signalling at several levels, increasing the expression of IGF-IR (Stewart et al. 1990a), in addition to IGF activators such as IRS-1 (Jackson et al. 1998, Lee et al. 1999, Molloy et al. 2000), and decreasing expression of IGFBPs such as IGFBP-3 (Huynh et al. 1996b). In addition, E2 activation of ER may cause a direct interaction between ER and IGF-IR, resulting in activation and phosphorylation of IGF-IR and downstream signals such as p42/p44 MAPK via a non-genomic mechanism (Kahlert et al. 2000, Marquez \& Pietras 2001, Powell et al. 2001). More recently, studies have suggested a role for shc and IGF-IR in mediating the translocation of ER to the plasma membrane leading to activation of p42/44 MAPK (Song et al. 2002, 2004). Although our previous studies have suggested that elevated ERBB2 is involved in the increased p42/44 MAPK activity and hence E2 hypersensitivity (Martin et al. 2003) it is possible that the non-genomic interaction of ER with IGF-IR may provide an alternate explanation for the enhanced p42/44 MAPK activity associated with this hypersensitive phenotype.

In this study we have shown that in LTED cells both the IGF-IR and, to a lesser extent, IRS-2 levels are increased two- to threefold in comparison with $\mathrm{Wt}$ cells (Fig. 4). The increase in IGF-IR levels might be a direct consequence of the significant increase in ER $\alpha$ content and ER-mediated gene transcription which has been observed in LTED cells (Jeng et al. 1998, Martin et al. 2003) and confirmed in this study. It is known that ER $\alpha$ rapidly activates the IGF pathway (Kahlert et al. 2000). In similar studies increases in IGF-IR levels in LTED cells have been noted and shown to correlate with a reversal of response to exogenously added ligand (Stephen et al. 2001). Insulin, IGF-I and IGF-II, which have a stimulatory effect on the proliferation of oestrogen-maintained cells, became inhibitory in LTED cells. Our observations on proliferation of LTED cells in response to various ligands are in agreement with this previous report, with E2 having an inhibitory effect on LTED cell growth in the presence of insulin. Daws et al. (1996) also reported that over-expression of IGF-IR may alter the proliferative response to E2, but at the same time demonstrated little effect on oestrogen-regulated gene expression. This would be consistent with our finding that, despite the change in proliferative response to oestrogen, we failed to demonstrate a similar shift in ERE gene transcription in LTED cells in the absence of insulin (Fig. 6A). These data imply that in LTED cells where IGF signalling may become enhanced, E2 may have paradoxical inhibitory effects on cell growth in the presence/absence of insulin, but that not all oestrogen-regulated genes may respond in the same way.

The effect of the two anti-oestrogens TAM and ICI on growth and ER-mediated gene transcription in LTED cells was also investigated. In LTED cells, TAM was largely ineffective and had only a minor inhibitory effect on growth and gene transcription at doses in excess of $10^{-7} \mathrm{M}$. ICI, however, inhibited cell growth in a dose-dependent manner (Fig. 1) with a matching reduction in ER-mediated gene transcription (Fig. 6) compared with the Wt cells, consistent with the drug's known effect in reducing levels of functioning ER as demonstrated in Fig. 5. Of interest, there was no significant effect of ICI on expression of the second isoform $\operatorname{ER} \beta$ (Fig. 5) and to our knowledge this is the first time this observation has been made. Competition of ICI with E2 at the ER $\beta$ ligand-binding domain is nonetheless expected to block signalling through ER $\beta$. Previous studies have associated enhanced expression of ER $\beta$ with resistance to TAM (Speirs et al. 1999); however, we found no evidence of any change in ER $\beta$ expression in the LTED cells versus the Wt cells.

In LTED cells, expression of IGF-IR and IRS-1/ IRS-2 was modulated by ICI, but not by TAM. In Wt MCF-7 cells, TAM is known to modulate IGF signalling by down-regulation of tyrosine phosphorylation of IGF-IR without affecting basal levels of receptor protein (Guvakova \& Surmacz 1997). The same group showed that cells engineered to overexpress IGF-IR became oestrogen independent, but that TAM could still modulate IGF signalling without affecting levels of IGF-IR protein (Surmacz \& Burgaud 1995, Guvakova \& Surmacz 1997). Likewise, others have shown that TAM on its own may not alter 
IRS-1 levels, although it may inhibit the induction of IRS-1 by E2 (Molloy et al. 2000). In contrast, several groups have previously demonstrated that ICI inhibits IGF signalling pathways in breast cancer cells, reducing expression of IGF-I (Huynh et al. 1996a), IRS-1 (Salerno et al. 1999), and downstream signalling including phosphorylation of phosphoinositide 3kinase (PI-3-K) and Akt-1 (Chan et al. 2001). Our data in LTED cells are supportive of the concept that $\mathrm{ER} \alpha$ remains a critical component for IGF signalling. For instance, in the absence of exogenous E2, ICI causes a decrease in ER $\alpha$ and IGF-IR expression in the LTED cells whilst in the Wt MCF-7 cells ICI causes a decrease in ER $\alpha$ but has no effect on IGF-IR (Fig. 5A and $\mathrm{B})$. We propose that this results from the hypersensitivity of the LTED cells to residual E2 in the DCC medium, hence ER signalling continues. However, in the Wt cells, ER is unliganded and thus cross-talk between ER and IGF-IR is absent. Conversely, in Wt cells treated with exogenous E2, ICI reduces expression of both ER $\alpha$ and IGF-IR (Fig. 9C). This view was further corroborated by experiments in an ER-negative breast cancer cell line where re-expression of $E R \alpha$ restored both oestrogen and IGF-mediated signalling and growth (Oesterreich et al. 2001).

Ultimately the basis for the differential effect of TAM versus ICI in the LTED cells relates to the different mechanisms of action of these two antioestrogens. In LTED cells, enhanced ER $\alpha$ expression and signalling appears to be central to the resistance mechanism. TAM alone is unable to have a significant effect, probably in part due to cross-talk and activation of ER in this system by peptide growth factors including the IGF pathway. TAM still allows ER dimerisation and DNA binding which may facilitate rather than antagonise ER-dependent growth in LTED cells; this is to some extent supported by our data (Fig. 3D and E) which indicate that in the presence of low doses of ICI (decreasing the amount of available ER) the agonist activity of TAM is revealed in the LTED cells. In contrast, the mode of action of ICI results in the targeted degradation of the ER $\alpha$ protein and hence is able to modulate endocrinedependent signalling, thus inhibiting growth in these LTED cells.

In summary, we have shown that while LTED cells are clearly resistant to TAM, they remain sensitive to the pure anti-oestrogen ICI. Our data suggest that inhibition by ICI occurs by negating $\mathrm{ER} \alpha$ signalling and not as a result of inhibition of growth factor receptor pathways as confirmed by our E2 rescue experiments (Fig. 2). We have shown that the LTED cells have enhanced ER $\alpha$ and IGF-IR/IRS-2 expression and signalling, and that the ability of ICI but not TAM to modulate this in LTED cells may account for the differential sensitivity to these two anti-oestrogens. This may have important implications for the therapeutic options utilised for women with ER-positive breast cancer that becomes resistant to long-term therapy with aromatase inhibitors. Although ICI appears particularly effective in this setting and clinical trials have shown it to be as efficient as anastrozole as a second-line therapy (for review see Buzdar 2003), concerns have been raised with regard to the escalating dose regime necessary to achieve maximal inhibition. As a result of these studies we believe that ICI in combination with an aromatase inhibitor will provide a more effective therapy for women who have relapsed on aromatase inhibitors, rather than ICI alone. In this setting where E2 levels remain suppressed by the aromatase inhibitor, lower doses of ICI would be required to give maximum benefit. Based upon these data we have initiated a clinical trial for treatment of women with advanced ER-positive disease who have relapsed on aromatase inhibitors. Patients will be randomised and treated with ICI, ICI plus anastrozole or exemestane. In conclusion, we believe that this study may provide a realistic alternative to current clinical practice.

\section{Acknowledgements}

SP and CMW were supported by a grant from The Breast Cancer Campaign (Charity No: 299758). We are also grateful to AstraZeneca UK for an educational grant and the supply of ICI for these studies. We would also like to express our gratitude to Paul Webb for the AP-1 reporter construct coll $\Delta 73$-luc. The authors declare that there is no conflict of interest that would prejudice the impartiality of this scientific work.

\section{References}

Ando S, Panno M-L, Salerno M, Sisci D, Mauro L, Lanzino M \& Surmacz E 1998 Role of IRS-1 signaling in insulin-induced modulation of estrogen receptors in breast cancer cells. Biochemical and Biophysical Research Communications 253 315-319.

ATAC Trialists' Group 2002 Anastrozole alone or in combination with tamoxifen versus tamoxifen alone for adjuvant treatment of postmenopausal women with early breast cancer: first results of the ATAC randomised trial. Lancet 359 2131-2139.

Bunone G, Briand PA, Miksicek RJ \& Picard D 1996 Activation of the unliganded estrogen receptor 
by EGF involves the MAP kinase pathway and direct phosphorylation. EMBO Journal 15 2174-2183.

Buzdar AU 2003 Advances in endocrine treatments for postmenopausal women with metastatic and early breast cancer. Oncologist 8 335-341.

Buzdar A \& Howell A 2001 Advances in aromatase inhibition: clinical efficacy and tolerability in the treatment of breast cancer. Clinical Cancer Research 7 2620-2635.

Buzdar A, Jonat W, Howell A, Jones SE, Blomqvist CP, Vogel CL, Eiermann W, Wolter JM, Steinberg M, Webster A \& Lee D 1998 Anastrozole versus megestrol acetate in the treatment of postmenopausal women with advanced breast carcinoma: results of a survival update based on a combined analysis of data from two mature phase III trials. Cancer 83 1142-1152.

Chan CMW, Martin L-A, Johnston SRD, Ali S \& Dowsett M 2002 Molecular changes associated with acquisition of estrogen hypersensitivity in MCF-7 breast cancer cells on long-term estrogen deprivation. Journal of Steroid Biochemistry and Molecular Biology 81 333-341.

Chan TW, Pollak M \& Huynh H 2001 Inhibition of insulinlike growth factor signaling pathways in mammary gland by pure antiestrogen ICI 182,780. Clinical Cancer Research 7 2545-2554.

Coutts AS \& Murphy LC 1998 Elevated mitogen-activated protein kinase activity in estrogen-nonresponsive human breast cancer cells. Cancer Research 58 4071-4074.

Darbre PD, Yates J, Curtis S \& King RJB 1983 Effect of estradiol on human breast cancer cells in culture. Cancer Research 43 349-354.

Daws MR, Westley BR \& May FEB Paradoxical effects of overexpression of the type-1 insulin-like growth factor (IGF) receptor on the responsiveness of human breast cancer cells to IGFs and estradiol. Endocrinology 137 1177-1186.

DeNardo DG, Kim HT, Hilsenbeck S, Cuba V, Tsimelzon A \& Brown PH 2005 Global gene expression analysis of estrogen receptor transcription factor cross talk in breast cancer: identification of estrogen-induced/activator protein-1-dependent genes. Molecular Endocrinology 19 $362-378$.

Dombernowsky P, Smith IE, Falkson G, Leonard R, Panasci L, Bellmunt J, Bezwoda W, Gardin G, Gudgeon A, Morgan M et al. 1998 Letrozole, a new oral aromatase inhibitor for advanced breast cancer: double-blind randomised trial showing a dose-effect and improved efficacy and tolerability compared with megestrol acetate. Journal of Clinical Oncology 16 453-461.

Dowsett M, Goss PE, Powles TJ, Hutchinson G, Brodie AM, Jeffcoate SL \& Coombes RC 1987 Use of the aromatase inhibitor 4-hydroxyandrostenedione in postmenopausal breast cancer: optimization of therapeutic dose and route. Cancer Research 47 1957-1961.

Geisler J, Haynes B, Anker G, Dowsett M \& Lonning PE 2002 Influence of letrozole and anastrozole on total body aromatization and plasma estrogen levels in postmenopausal breast cancer patients evaluated in a randomized, cross-over study. Journal of Clinical Oncology 20 751-757.

Guvakova MA \& Surmacz E 1997 Tamoxifen interferes with the insulin-like growth factor I receptor (IGF-1R) signaling pathway in breast cancer cells. Cancer Research 57 2606-2610.

Huynh H, Nickerson T, Pollak M \& Yang X $1996 a$ Regulation of insulin-like growth factor I receptor expression by the pure antiestrogen ICI 182780. Clinical Cancer Research 2 2037-2042.

Huynh HT, Yang X \& Pollack M $1996 b$ Estradiol and anti-estrogens regulate a growth inhibitory insulin-like growth factor binding protein 3 autocrine loop in human breast cancer cells. Journal of Biological Chemistry 271 1016-1021.

Ishikawa T, Takano K, Yasufuku-Takano J, Fujita T, Igarashi T, Miura M \& Hata K 2001 Estrogenic impurities in labware. Nature Biotechnology 19812.

Jackson JG, White MF \& Yee D 1998 Insulin receptor substrate- 1 is the predominant signaling molecule activated by insulin-like growth factor-1, insulin, and interleukin-4 in estrogen receptor positive human breast cancer cells. Journal of Biological Chemistry 273 9994-10003.

Jeng M-H, Shupnik MA, Bender TP, Westin EH, Bandyopadhyay D, Kumar R, Masamura S \& Santen RJ 1998 Estrogen receptor expression and function in long-term estrogen-deprived human breast cancer cells. Endocrinology 139 4164-4174.

Johnston SR \& Dowsett M 2003 Aromatase inhibitors for breast cancer: lessons from the laboratory. Nature Reviews in Cancer 3 821-831.

Kahlert S, Nuedling S, van Eickels M, Vetter H, Meyer R \& Grohe C 2000 Estrogen receptor $\alpha$ rapidly activates the IGF-1 receptor pathway. Journal of Biological Chemistry 275 18447-18453.

Lee AV, Jackson JG, Gooch JL, Hilsenbeck SG, CoronadoHeinsohn E, Osborne CK \& Yee D 1999 Enhancement of insulin-like growth factor signaling in human breast cancer: estrogen regulation of insulin receptor substrate-1 expression in vitro and in vivo. Molecular Endocrinology 13 787-796.

Lewis JS, Osipo C, Meeke K \& Jordan VC 2005 Estrogeninduced apoptosis in a breast cancer model resistant to long-term estrogen withdrawal. Journal of Steroid Biochemistry and Molecular Biology 94 131-141.

Liu H, Lee ES, Gajdos C, Pearce ST, Chen B, Osipo C, Loweth J, McKian K, De Los Reyes A, Wing L \& Jordan VC 2003 Apoptotic action of 17beta-estradiol in raloxifene-resistant $\mathrm{MCF}-7$ cells in vitro and in vivo. Journal of the National Cancer Institute 95 1586-1597.

McClelland RA, Gee JMW, Francis AB, Robertson JF, Blamey RW, Wakeling AE \& Nicholson RI 1996 Short-term effects of pure antiestrogen ICI 182780 treatment on estrogen receptor, epidermal growth factor receptor and transforming growth factor-alpha protein 
expression in human breast cancer. European Journal of Cancer 32A 413-416.

Marquez DC \& Pietras RJ 2001 Membrane-associated binding sites for estrogen contribute to growth regulation of human breast cancer cells. Oncogene 20 5420-5430.

Martin LA, Farmer I, Johnston SR, Ali S, Marshall C \& Dowsett M 2003 Enhanced estrogen receptor (ER) alpha, ERBB2, and MAPK signal transduction pathways operate during the adaptation of MCF-7 cells to long term estrogen deprivation. Journal of Biological Chemistry 278 30458-30468.

Masamura S, Santner SJ, Heitjan DF \& Santen RJ 1995 Estrogen deprivation causes estradiol hypersensitivity in human breast cancer cells. Journal of Clinical Endocrinology and Metabolism 80 2918-2925.

Molloy CA, May FEB \& Westley BR 2000 Insulin receptor substrate-1 expression is regulated by estrogen in the MCF-7 human breast cancer cell line. Journal of Biological Chemistry 275 12565-12571.

Mouridsen H, Gershanovich M, Sun Y, Pérez-Carrión R, Boni C, Monnier A, Apffelstaedt J, Smith R, Sleeboom HP, Jänicke F et al. 2001 Superior efficacy of letrozole (femara) versus tamoxifen as first-line therapy for postmenopausal women with advanced breast cancer: results of a phase III study of the International Letrozole Breast Cancer Group. Journal of Clinical Oncology 19 2596-2606.

Nabholtz JM, Buzdar A, Pollak M, Harwin W, Burton G, Mangalik A, Steinberg M, Webster A \& von Euler M 2000 Anastrozole is superior to tamoxifen as first-line therapy for advanced breast cancer in postmenopausal women: results of a North American multicentre randomised trial. Journal of Clinical Oncology 18 3758-3767.

Nicholson RI, McCelland RA, Robertson JF \& Gee JM 1999 Involvement of steroid hormone and growth factor cross-talk in endocrine response in breast cancer. Endocrine-Related Cancer 6 373-387.

Oesterreich S, Zhang P, Guler RL, Sun X, Curran EM, Welshons WV, Osborne CK \& Lee AV 2001 Re-expression of estrogen receptor a in estrogen receptor a-negative $\mathrm{MCF}-7$ cells restores both estrogen and insulin-like growth factor mediated signaling and growth. Cancer Research 61 5771-5777.

Osipo C, Gajdos C, Lui H, Chen B \& Jordan VC 2003 Paradoxical action of fluvistrant in estradiol induced regression of tamoxifen stimulated breast cancer. Journal of the National Cancer Institute 95 1597-1608.

Powell CE, Soto AM \& Sonnenschein C 2001 Identification and characterization of membrane estrogen receptor from MCF-7 estrogen-target cells. Journal of Steroid Biochemistry and Molecular Biology 77 97-108.

Rajah TT, Dunn ST \& Pento JT 1996 The influence of anti-estrogens on pS2 and cathepsin D mRNA induction in MCF-7 breast cancer cells. Anticancer Research 16 $837-842$.

Salerno M, Sisci D, Mauro L, Guvakova MA, Ando S \& Surmacz E 1999 Insulin receptor substrate 1 is a target for the pure anti-estrogen ICI 182780 in breast cancer cells. International Journal of Cancer $\mathbf{8 1}$ 299-304.

Santen R, Jeng M-H, Wang J-P, Song R, Masamura S, McPherson R, Santner S, Yue W \& Shim WS 2001 Adaptive hypersensitivity to estradiol: potential mechanism for secondary hormonal responses in breast cancer patients. Journal of Steroid Biochemistry and Molecular Biology 79 115-125.

Shaulian E \& Karin M 2001 AP-1 in cell proliferation and survival. Oncogene 20 2390-2400.

Shim WS, Conaway M, Masamura S, Yue W, Wang J-P, Kumar R \& Santen RJ 2000 Estradiol hypersensitivity and mitogen-activated protein kinase expression in longterm estrogen deprived human breast cancer cells in vivo. Endocrinology 141 396-405.

Smith PJ, Wise LS, Berkowitz R, Wan C \& Rubin CS 1988 Insulin-like growth factor-I is an essential regulator of the differentiation of 3T3-L1 adipocytes. Journal of Biological Chemistry 263 9402-9408.

Song RXD, Mor G, Naftolin F, McPherson RA, Song J, Zhang Z, Yue W, Wang J-P \& Santen RJ 2001 Effect of long term oestrogen deprivation on apoptotic responses of breast cancer cells to $17 \beta$-estradiol. Journal of the National Cancer Institute 93 1714-1723.

Song RX, McPherson RA, Adam L, Bao Y, Shupnik M, Kumar R \& Santen RJ 2002 Linkage of rapid estrogen action to MAPK activation by ERalpha-Shc association and Shc pathway activation. Molecular Endocrinology 16 116-127.

Song RX, Barnes CJ, Zhang Z, Bao Y, Kumar R \& Santen RJ 2004 The role of Shc and insulin-like growth factor 1 receptor in mediating the translocation of estrogen receptor alpha to the plasma membrane. PNAS 101 2076-2081.

Song RX, Zhang Z, Mor G \& Santen RJ 2005 Downregulation of Bcl-2 enhances estrogen apoptotic action in long-term estradiol-depleted ER + breast cancer cells. Apoptosis 10 667-678.

Speirs V, Malone C, Walton DS, Kerin MJ \& Atkin S 1999 Increased expression of estrogen receptor $\beta$ mRNA in tamoxifen-resistant breast cancer patients. Cancer Research 59 5421-5424.

Stephen RL, Shaw LE, Larsen C, Corcoran D \& Darbre PD 2001 Insulin-like growth factor receptor levels are regulated by cell density and by long-term estrogen deprivation in MCF-7 human breast cancer cells. Journal of Biological Chemistry 276 40080-40086.

Stewart AJ, Johnson MD, May FEB \& Westley BR $1990 a$ The role of IGFs and type I IGF receptor in the estrogen stimulated proliferation of human breast cancer cells. Journal of Biological Chemistry $\mathbf{2 6 5}$ 21172-21178. 
Stewart AJ, Johnson MD, May FE \& Westley BR $1990 b$ Role of insulin-like growth factors and the type I insulin-like growth factor receptor in the estrogen-stimulated proliferation of human breast cancer cells. Journal of Biological Chemistry $\mathbf{2 6 5}$ 21172-21178.

Surmacz E \& Burgaud JL 1995 Overexpression of insulin receptor substrate 1 (IRS-1) in the human breast cancer cell line MCF-7 induces loss of estrogen requirements for growth and transformation. Clinical Cancer Research 1 1429-1436.
Wakeling AE \& Bowler J 1992 ICI 182,780, a new antiestrogen with clinical potential. Journal of Steroid Biochemistry and Molecular Biology $\mathbf{4 3}$ 173-177.

Webb P, Nguyen P, Valentine C, Lopez GN, Kwok GR, McInerney E, Katzenellenbogen BS, Enmark E, Gustafsson JA, Nilsson S \& Kushner PJ 1999 The estrogen receptor enhances AP-1 activity by two distinct mechanisms with different requirements for receptor transactivation functions. Molecular Endocrinology 13 $1672-1685$. 